\title{
Kapabilitas Dynamic Governance Dalam Pencapaian Pertumbuhan Ekonomi Provinsi Kepulauan Riau Tahun 2012 - 2017
}

\author{
Donie Tuah Fitriano Putra \\ Magister Ilmu Pemerintahan, Fakultas Ilmu Sosial dan Ilmu Politik \\ Universitas Padjadjaran \\ donietuah@gmail.com
}

\begin{abstract}
The economic growth of the Riau Islands Province has decreased from 2012 to 2017. The government as the main actor in governance has become an institution that must be more responsive, bringing up adaptive policies as a solution. Government capability is a measure of the success of economic performance in achieving economic growth. This study aims to analyze the capabilities of the government in achieving economic growth in the Riau Islands Province in 2012-2017. Government capabilities are analyzed and described using six indicators in the theory of Dynamic Governance, namely: (1) Thinking ahead; (2) Thinking again; (3) Thinking across; (4) Able people; (5) Agile Process; (6) Culture. The research method used is a qualitative research method. The results showed that the capabilities of the Riau Islands Province government did not yet reflect the capabilities of dynamic governance. Where four of the six indicators have not been realized in the administration of government. Adaptive policies produced in the implementation are not consistently carried out, even some are not running which ultimately is not able to increase regional economic growth.
\end{abstract}

\section{Keywords: Dynamic Governance Capability, Adaptive Policy, Economic Growth}

\begin{abstract}
Abstrak
Pertumbuhan ekonomi Provinsi Kepulauan Riau mengalami penurunan sejak tahun 2012 hingga 2017. Pemerintah sebagai aktor utama governance menjadi insititusi yang harus lebih responsif, memunculkan kebijakan yang adaptif sebagai solusi. Kapabilitas pemerintah menjadi ukuran keberhasilan kinerja perekonomian dalam pencapaian pertumbuhan ekonomi. Penelitian ini bertujuan untuk menganalisis kapabilitas pemerintah dalam pencapaian pertumbuhan ekonomi Provinsi Kepulauan Riau tahun 2012-2017. Kapabilitas pemerintah dianalisis dan dideskripsikan menggunakan enam indikator dalam teori Dynamic Governance, yakni: (1) Thinking ahead; (2) Thinking again; (3) Thinking across; (4) Able people; (5) Agile Process; (6) Culture. Metode penelitian yang digunakan adalah metode penelitian kualitatif. Hasil penelitian menunjukkan bahwa kapabilitas pemerintah Provinsi Kepulauan Riau belum mencerminkan kapabilitas dynamic governance. Di mana empat dari enam indikator belum terwujud pada penyelenggaraan pemerintahan. Kebijakan adapatif yang dihasilkan dalam implementasinya tidak konsisten dilakukan, bahkan ada yang tidak berjalan yang akhirnya tidak mampu meningkatkan pertumbuhan ekonomi daerah.
\end{abstract}

Kata kunci: Kapabilitas Dynamic Governance, Kebijakan Adaptif, Pertumbuhan Ekonomi 



\section{Pendahuluan}

Otonomi daerah telah memberikan peluang bagi daerah untuk melakukan perubahan, perbaikan, dan pembangunan demi kemajuan daerah. Ada empat sasaran fundamental terkait dengan pembangunan yang ingin dicapai oleh daerah (Kuncoro, 2014: 182), yaitu: (1) meningkatkan laju pertumbuhan ekonomi daerah; (2) meningkatkan pendapatan per kapita; (3) mengurangi kemiskinan, pengangguran, dan ketimpangan; (4) meningkatkan kualitas sumberdaya manusia (IPM). Daerah memiliki kewenangan dalam menggali potensi dan mengelola keuangan daerah sendiri untuk mencapai sasaran pembangunan tersebut. Artinya pemerintah daerah memiliki peran yang sangat dominan dalam merencanakan dan menentukan arah prioritas pembangunan, menggali sumber-sumber penerimaan daerah, serta mengelola dan memanfaatkannya sesuai dengan aspirasi masyarakat. Pemerintah daerah harus menunjukkan komitmennya dalam mengoptimalkan sumber-sumber penerimaan guna peningkatan pembangunan daerah. Oleh karena itu, sudah seharusnya pembangunan daerah pasca otonomi daerah mengalami peningkatan yang signifikan dibanding sebelumnya.

Pertumbuhan ekonomi terkait dengan tata kelola ekonomi (economic governance), di mana sinergi antar aktor governance, yaitu: pemerintah, swasta, dan masyarakat sangat diperlukan guna terciptanya peningkatan pertumbuhan ekonomi yang berkualitas dan berkelanjutan. Tentunya peran dan keterlibatan pemerintah lebih dominan dibanding dengan kedua aktor governance lainnya, karena pemerintah memiliki kewenangan yang besar dalam mengatur aktivitas perekonomian melalui berbagai kebijakannya. Oleh karena itu pemerintah harus memiliki kapabilitas dalam menggerakkan aktivitas perekonomian. Pemerintah harus memiliki visi pembangunan ekonomi yang jelas, melihat berbagai peluang dan dapat mengantisipasi berbagai ancaman atau hambatan. Pemerintah tidak boleh hanya menuruti kemauan yang terjadi dalam mekanisme pasar, yang lebih didominasi keinginan swasta untuk mendapatkan keuntungan besar. Di sisi lain pemerintah harus memikirkan masyarakat untuk dapat ikut terlibat dalam aktivitas perekonomian dan menikmati hasil pembangunan ekonomi. Dengan kata lain, kapabilitas pemerintah diuji untuk dapat menyeimbangkan apa yang menjadi keinginan swasta dan masyarakat dalam rangka mewujudkan peningkatan pertumbuhan ekonomi yang berkualitas dan berkelanjutan.

Laju pertumbuhan ekonomi Provinsi Kepulauan Riau dari tahun 2012 hingga tahun 2017 terus mengalami penurunan. Pada tahun 2012 laju pertumbuhan ekonomi sebesar 7,63\%, kemudian berturut-turut mengalami penurunan yaitu: tahun 2013 sebesar 7,21\%, tahun 2014 sebesar 6,60\%, tahun 2015 sebesar 6,01\%, tahun 2016 sebesar 5,03\%, dan di tahun 2017 hanya tumbuh sebesar 2\%, jauh dari target yang ingin dicapai yaitu sebesar 5,85\% (BPS Provinsi Kepulauan Riau, 2018). Bahkan angka 
ini jauh di bawah angka pertumbuhan ekonomi nasional tahun 2017, yang tumbuh sebesar 5,07\%. Apabila merujuk pada tahun-tahun sebelumnya, pertumbuhan ekonomi Provinsi Kepulauan Riau sama atau bahkan di atas pertumbuhan ekonomi nasional.

Turunnya pertumbuhan ekonomi ini menunjukkan bahwa perekonomian Provinsi Kepulauan Riau sedang tidak kondusif. Dimulai dengan ambruknya 3 (tiga) sektor utama penopang perekonomian, yakni industri pengolahan; konstruksi; dan pertambangan dan penggalian. Ketiga sektor ini berkontribusi rata-rata sebesar $71,71 \%$ terhadap Produk Domestik Regional Bruto (PDRB) tiap tahunnya (BPS Provinsi Kepulauan Riau, 2018). Namun, besarnya kontribusi ketiga sektor usaha tersebut tidak diikuti dengan peningkatan pertumbuhan yang signifikan. Pertumbuhan ketiganya terus mengalami penurunan sehingga berdampak besar pada pertumbuhan ekonomi Provinsi Kepulauan Riau. Pertumbuhan sektor lain sebenarnya cukup menjanjikan, namun kontribusinya terhadap PDRB sangat kecil maka kurang berpengaruh besar pada peningkatan pertumbuhan ekonomi Provinsi Kepulauan Riau. Di sinilah persoalannya, pemerintah belum banyak melakukan upaya untuk mereorientasi kebijakan pembangunan ekonomi untuk tidak terlalu tergantung pada ketiga sektor tersebut. Padahal beberapa sektor yang sangat potensial seperti kelautan, perikanan dan pariwisata seharusnya bisa menjadi alternatif sektor unggulan untuk meningkatkan pertumbuhan ekonomi.

Kemudian, pertumbuhan investasi yang juga mengalami penurunan. Di mana tahun 2012 pertumbuhan investasi sebesar 7,53\%, kemudian berturut-turut mengalami penurunan hingga tahun 2017, yaitu tahun 2013 sebesar 6,62\%, tahun 2014 sebesar 5,79\%, tahun 2015 sebesar 3,25\%, tahun 2016 sebesar 3,21\%, dan tahun 2017 sebesar 3,13\%. (BPS Provinsi Kepulauan Riau, 2018). Investasi merupakan salah satu faktor utama yang sangat berpengaruh terhadap pertumbuhan ekonomi. Investasi memainkan peran yang sangat penting sebagai pendorong aktivitas perekonomian di daerah, karena dengan investasi maka terjadi peningkatan modal untuk memperbesar kapasitas produksi sehingga mampu menciptakan lapangan kerja baru, terbuka kesempatan kerja bagi masyarakat, yang pada akhirnya mampu meningkatkan pendapatan.

Perkembangan investasi berkaitan dengan iklim investasi dan daya saing ekonomi daerah. Investor menginginkan daerah memiliki keunggulan yang menjadi daya tarik untuk berinvestasi, seperti ketersediaan infrastruktur, tenaga kerja, bahan baku, keamanan, kebijakan ekonomi, dan tentunya iklim investasi yang kondusif. Hasil survei Indonesia Provincial Competitiveness yang dilakukan oleh Asia Competitiveness Institute menunjukkan bahwa daya saing Provinsi Kepulauan Riau berada pada peringkat 11 di tahun 2014, peringkat 7 di tahun 2015, peringkat 12 di tahun 2016, dan peringkat 10 di tahun 2017 dari 33 provinsi. Secara keseluruhan Provinsi Kepulauan Riau memiliki daya saing yang baik. Namun, tata kelola pemerintahan daerah Provinsi Kepulauan Riau 
belum dapat mendukung peningkatan daya saing daerah. Hal ini terlihat dari hasil survei tersebut bahwa daya dukung pemerintah Provinsi Kepulauan Riau terhadap daya saing daerah berada diperingkat 31 di tahun 2014, peringkat 18 di tahun 2015, peringkat 32 tahun 2016, dan peringkat 32 di tahun 2017 (Asia Competitiveness Institute, 2017).

Selain itu, hasil penilaian kepatuhan pelayanan publik yang dilakukan oleh Ombudsman Republik Indonesia tahun 2015-2017 menunjukkan bahwa pemerintah Provinsi Kepulauan Riau masuk dalam zona kuning dengan nilai 71,88 di tahun 2015, 66,11 di tahun 2016, 74,83 di tahun 2017. Ada enam Organisasi Perangkat Daerah (OPD) yang dinilai yakni, Dinas Energi Sumber Daya Mineral (ESDM), Dinas Koperasi dan UKM, Dinas Penanaman Modal Pelayanan Terpadu Satu Pintu (DPMPTSP), Dinas Pekerjaan Umum Penataan Ruang dan Pertanahan (PUPRP), Dinas Pendidikan (Disdik), Dinas Sosial (Dinsos). Dari keenam OPD tersebut hanya DPMPTSP yang mendapatkan nilai rendah dan berada di zona merah, yang mengindikasikan bahwa pelayanan publik pada dinas tersebut buruk. Padahal DPMPTSP merupakan ujung tombak pelayanan publik yang mampu mendorong terciptanya iklim investasi yang kondusif.

Selain investasi, konsumsi pemerintah juga mempengaruhi pertumbuhan ekonomi. Walaupun kontribusinya sangat kecil, namun komponen ini mampu menstimulus atau mendorong pertumbuhan ekonomi. Pengeluaran yang dialokasikan untuk pembangunan akan berdampak pada peningkatan aktivitas perekonomian. Konsumsi pemerintah merupakan bagian dari kebijakan fiskal, besar kecilnya pengeluaran dipengaruhi oleh komponen belanja pegawai, belanja barang dan jasa, belanja modal, belanja bantuan sosial dan belanja pemerintah lainnya. Faktanya, konsumsi pemerintah Provinsi Kepulauan Riau yang merupakan konsumsi pemerintah terbesar dibanding dengan pemerintah kabupaten/ kota dan instansi vertikal yang ada di daerah mengalokasi belanja rutin atau pegawai lebih besar dibanding belanja pembangunan, yaitu rata-rata $51,83 \%$ per tahun (Ditjen Perimbangan Keuangan Kemenkeu, 2018).

Ditambah dengan realisasi pendapatan dan belanja yang bergerak fluktuatif. Realisasi pendapatan di tahun 2012 sebesar 121,35\%, di tahun 2013 meningkat sebesar 125,09\%, di tahun 2014 turun menjadi 98,27\%, lalu di tahun 2015 hanya sebesar 77,92\%, kemudian mulai meningkat kembali di tahun 2016 sebesar 83,41\%, dan di tahun 2017 menjadi sebesar 101,58\%. Perkembangan realisasi belanja mengikuti ritme realisasi pendapatan, tahun 2012 sebesar 94, 22\%, meningkat di tahun 2013 sebesar 110,58\%, di tahun 2014 turun menjadi 95,74\%, lalu di tahun 2015 hanya sebesar 70,96\%, kemudian mengalami peningkatan di tahun 2016 sebesar 79,74\%, dan di tahun 2017 menjadi sebesar 97,37\%. (Ditjen Perimbangan Keuangan Kemenkeu, 2018).

Realisasi pendapatan yang menurun mengindikasikan kurang mampunya pemerintah dalam menggali sumber-sumber pendapatan, yang tentunya akan 
148| Donie Tuah F. Kapabilitas Dynamic...

mempengaruhi pelaksanaan program-program pembangunan daerah. Kemudian, menurunnya realisasi belanja mengindikasikan kurang mampunya pemerintah dalam membelanjakan atau penyerapan anggaran dalam menjalankan program-program yang telah disusun. Pemerintah biasanya merealisasikan anggaran belanja hanya tertumpu pada akhir tahun saja, maka ini kurang memberikan dampak yang signifikan pada pertumbuhan ekonomi.

Mengacu pada realita di atas, maka pemerintah dituntut untuk melakukan berbagai inovasi kebijakan yang adaptif sesuai dengan kondisi perekonomian yang berkembang. Pemerintah harus bergerak dinamis merencanakan dan mengimplementasikan inovasi kebijakan-kebijakan untuk menjawab persoalan terkait pertumbuhan ekonomi. Perumusan dan pengimplementasian kebijakan berkaitan erat dengan kapabilitas pemerintah, seperti yang dijelaskan oleh Neo \& Chen tentang dynamic governance di Singapura. Bagaimana kebijakan adaptif dihasilkan dan dieksekusi melalui pengembangan dynamic capabilities (mencakup kemampuan thinking ahead, thinking again, dan thingking across) dan didukung oleh able people, agile process, dan culture yang telah mengantarkan Singapura menjadi kekuatan ekonomi di dunia. Oleh karena itu, penelitian ini bertujuan untuk menganalisis kapabilitas Pemerintah Provinsi Kepulauan Riau dalam pencapaian pertumbuhan ekonomi tahun 2012 - 2017 dengan menggunakan pendekatan dynamic governance.

\section{Tinjauan Pustaka}

\section{A. Konsep Governance}

Kemunculan governance dipandang sebagai suatu alternatif cara pandang dalam memahami dinamika perubahan sosial, ekonomi dan politik. Terjadinya pergeseran kata government kepada governance tidak lepas dari peran World Bank dan United Nations Development Programme (UNDP) beserta lembaga donor Internasional lainnya yang mengembangkan istilah governance sebagai pendamping government. Pendamping di sini dimaksudkan bahwa yang berperan dalam suatu negara bukan hanya "government" atau pemerintah saja. Ada aktor-aktor lainnya yang ikut berperan atau mendampingi pemerintah. Istilah governance inilah yang kemudian menjadi populer digunakan oleh kalangan akademisi, pembuat kebijakan, birokrat maupun masyarakat.

World Bank (1994: vii) memberikan definisi governance secara lebih substansial, yakni:

Governance is epitomized by predictable, open and enlightened policy making (that is transparent processes): a bureaucracy imbued with professional ethos; an executive arm of government accountable for its actions; and a strong civil society participating in public affairs and all behaving under the rule of law. 
Dari definisi ini, dapat dipahami bahwa tata kelola pemerintahan dilambangkan sebagai proses pembuatan kebijakan yang jelas, terbuka dan bisa diprediksi (yakni melalui proses yang transparan): birokrasi yang diilhami oleh etos profesional; lembaga pemerintahan yang akuntabel atas tindakan-tindakannya; kemudian partisipasi masyarakat sipil yang kuat dalam masalah-masalah publik dan semua tindakan yang dilakukan didasari atas aturan hukum.

Sedangkan United Nations Development Programme (UNDP) dalam dokumen kebijakannya yang berjudul Governance for Sustainable Human Development, (1997: 9) mendefinisikan governance, yakni:

Governance is defined as the exercise of political, economic and administrative authority to manage a nation's affairs. It is the complex mechanisms, processes, relationships and institutions through which citizens and groups articulate their interests, exercise their rights and obligations and mediate their differences.

UNDP mendefinisikan governance sebagai penggunaan kewenangan politik, ekonomi, dan administratif untuk mengelola urusan negara. Di mana penekanan dari definisi ini adalah mengenai kewenangan, kekuasaan yang sah atau kekuasan yang memiliki legitimasi pada aspek politik, ekonomi dan adminisratif dalam pengelolaan negara. Dari ketiga aspek tersebut, UNDP merumuskan ke dalam tiga aktor yang berperan dalam governance, yaitu negara atau pemerintah (state); sektor swasta atau dunia usaha (private sector); dan masyarakat (civil society).

Boon Siong Neo dan Geraldine Chen (2007: 52) memaknai governance sebagai "the choosen path, policies, institutions and the resultant structures that collectively provide the incentives and constraints to facilitate or impede interactions that lead to economic progress and social wellbeing". Governance merupakan penentuan berbagai kebijakan, institusi dan struktur yang dipilih, yang secara bersama mendorong untuk memudahkan interaksi ke arah kemajuan ekonomi dan kehidupan sosial yang lebih baik. Governance menjadi sebuah pilihan cara atau proses dalam merumuskan kebijakan untuk mewujudkan tujuan bersama.

Dengan memahami definisi governance dari berbagai pendapat di atas, maka dapat ditarik simpulan bahwa governance atau tata kelola pemerintahan merupakan mekanisme atau sistem pengelolaan urusan negara yang dilakukan oleh aktor-aktor baik dari pemerintah maupun non-pemerintah dengan segala kekuasaan dan kewenangan yang dimilikinya, di mana meraka saling berinteraksi dalam pengambilan keputusan atau kebijakan secara kolektif serta dalam pengimplementasian kebijakan tersebut.

\section{B. Model Dynamic Governance}

Boon Siong Neo dan Geraldine Chen (2007: 52) merumuskan dynamic governance sebagai "to how these choosen paths, policies, institutions, and structures adapt to an uncertain and fast changing envinronment so that they remain relevant and 
effective in achieving the long-term desired outcomes of society". Pendapat Neo dan Chen ini menunjukkan bahwa dynamic governance adalah suatu mekanisme atau pola tentang bagaimana bekerjanya berbagai kebijakan, institusi dan struktur yang telah dipilih agar mampu beradaptasi dengan kondisi yang tidak menentu dan perubahan lingkungan yang cepat sehingga kebijakan, institusi dan struktur tersebut agar tetap relevan dan efektif dalam pencapaian keinginan masyarakat.

Dynamic governance menekankan pemerintah untuk dapat memperhatikan faktor eksternal lingkungan kebijakan. Kebijakan yang adaptif bukan hanya sekedar reaksi yang pasif terhadap tekanan eksternal namun pendekatan proakif terhadap inovasi, kontekstualisasi, dan implementasi (Andhika, 2017: 93). Inovasi kebijakan berarti gagasan yang baru yang dimasukkan dalam kebijakan untuk mencapai hasil yang lebih baik dan berbeda. Namun bukan hanya tentang ide atau gagasan baru dalam bentuk kontekstual perencanaan saja, tetapi juga terkait dengan implementasi kebijakannya. Dengan dynamic governance dapat tercipta pemerintahan yang cepat, responsif dan inovatif dalam menghadapi dinamika perubahan lingkungan yang terjadi.

Dynamic governance dapat dipahami sebagai adanya saling ketergantungan antara budaya dan kapabilitas pemerintah, yang ditopang dengan kemampuan orang/ aktor dan mekanisme atau proses yang baik, di mana interaksi antara pemerintah dengan lingkungan ekternalnya mampu untuk dapat merumuskan dan mengimplementasikan kebijakan yang adaptif seperti terlihat pada gambar berikut.

\section{Gambar 2.1: Framework for Dynamic Governance System}

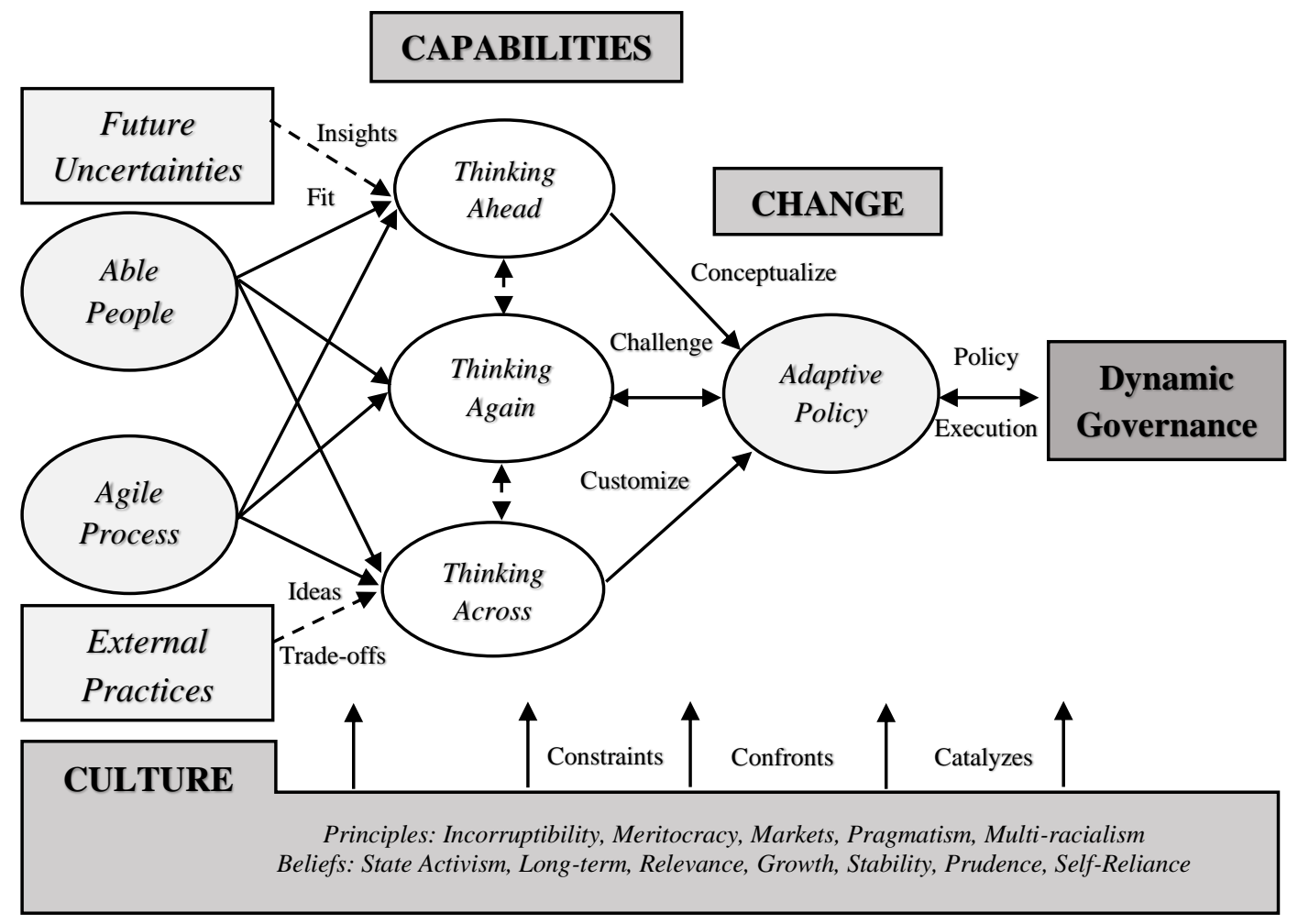


Sumber: Neo dan Chen, 2007: 13

Budaya akan sangat mempengaruhi setiap aktivitas kegiatan pemerintah. Neo dan Chen (2007: 3) memberikan argumentasi tentang cara menjadi salah satu negara maju, "a foundation of cultural values and beliefs can work synergistically with strong organizational capabilities to create a dynamic governance system that enables continous change." Budaya dapat bersinergi dengan kemampuan organisasi yang kuat sehingga menciptakan pemerintahan dinamis yang memungkinkan terjadinya perubahan.

Menurut Neo dan Chen (2007: 25) budaya mempengaruhi pemerintahan dalam tiga cara. Pertama, budaya membatasi (constraints) agenda dan proses dalam perumusan kebijakan. Isu-isu yang bertentang dengan nilai dan prinsip budaya cenderung kurang dapat diterima atau dipertimbangkan dalam proses pengambilan kebijakan. Kedua, nilai-nilai budaya sering digunakan untuk mempertimbangkan pilihan kebijakan inovatif yang bertentangan (confronts). Efek dari adanya pertentangan antara pilihan kebijakan tersebut dengan nilai-nilai budaya ini mengakibatkan adanya hambatan atau bahkan tidak diterimanya kebijakan tersebut. Ketiga, nilai-nilai budaya mengkatalisasi atau mempercepat (catalyzes) para pengambil kebijakan untuk secara aktif mencari alternatif dan ide-ide yang selaras dan akan mempercepat tercapainya tujuan.

Kapabilitas menurut Neo dan Chen (2007: 29) merujuk pada "an organization's attitude, knowledge, skills and resources deployed in conceiving and performing important coordinated tasks to achieve desired results". Pendapat ini menunjukkan bahwa kapabilitas dalam dynamic governance sebagai sikap, pengetahuan, keterampilan, dan sumber daya organisasi yang digunakan untuk memahami dan melaksanakan tugas yang dikoordinasikan untuk mencapai hasil yang diinginkan. Yang paling utama ialah kemampuan pemimpin, di mana pemimpin memiliki kemampuan dan pengaruh yang besar untuk menggerakkan bawahan maupun stakeholder lainnya untuk melakukan perubahan.

Ada tiga karakteristik kapabilitas dalam dynamic governance (Neo dan Chen, 2007: 30-44). Pertama, thinking ahead (berpikir ke depan) merupakan kemampuan mengidentifikasi faktor lingkungan berpengaruh pada pelaksanaan pembangunan di masa mendatang. Mendorong institusi pemerintah untuk menilai dan meninjau kembali kebijakan dan strategi yang sedang berjalan, memperbaharui target dan tujuan, dan menyusun konsep baru kebijakan yang dipersiapkan menyongsong masa depan.

Kedua, thinking again (berpikir kembali) merupakan kemampuan meninjau kembali berbagai kebijakan, strategi, dan program yang sedang berjalan. Apakah hasil yang dicapai oleh kebijakan, strategi, dan program telah memenuhi harapan banyak 
152| Donie Tuah F. Kapabilitas Dynamic...

pihak atau perlu didesain ulang untuk mendapatkan kualitas hasil yang lebih baik sesuai dengan kondisi yang sedang dihadapi dan masa mendatang.

Ketiga, thinking across (berpikir lintas batas) merupakan kemampuan untuk mengadopsi pikiran, pendapat, ide-ide lain di luar kerangka berpikir (mindset) yang secara tradisional telah melekat dan menjadi dasar untuk melakukan sesuatu. Dapat juga dikatakan sebagai cara untuk melakukan benchmarking to best practise dari negara atau pemerintahan lain yang bersifat inovatif dan kreatif.

Ketiga kemampuan ini harus didukung oleh orang yang memiliki kemampuan (able people) dan harus dilakukan dengan proses yang cepat, tangkas dan baik/ benar (agile process). Able people artinya adalah orang-orang yang dapat atau mampu melihat membaca masa depan berdasarkan fakta, gejala dan perkembangan masa kini ditambah proyeksi akibat perubahan global yang cepat. Able people juga bermakna orang yang memiliki kewenangan, karena banyak orang memiliki kemampuan seperti disebut di atas tetapi tidak memiliki kesempatan dan kewenangan (kewenangan formal/ kewenangan akademik). Agile process berkaitan dengan cara, mekanisme atau prosedur yang benar dalam melakukan thinking ahead, thinking again, dan thinking across, cara yang benar dimaksud adalah berdasarkan prinsip-prinsip ilmiah tidak tercampur dengan kehendak pribadi atau terkontaminasi keinginan politik kelompok tertentu atau sekedar formalitas untuk menghabiskan anggaran.

\section{Pertumbuhan Ekonomi}

Simon Kuznets (1973: 247) mendefinisikan pertumbuhan ekonomi sebagai "a long term rise in capacity to supply increasingly diverse economic goods to its population, this growing capacity based on advancing technology and the institutional and ideological adjustments that it demands". Pendapat ini menunjukkan bahwa pertumbuhan ekonomi merupakan kenaikan jangka panjang dalam kemampuan negara untuk menyediakan berbagai jenis barang-barang ekonomi kepada penduduknya yang terus meningkat, kemampuan ini tumbuh sesuai dengan kemajuan teknologi, penyesuaian kelembagaan dan ideologis yang diperlukan.

Definisi ini memiliki tiga komponen: pertama, pertumbuhan ekonomi terlihat dari meningkatnya secara terus menerus persediaan barang. Kedua, kemajuan teknologi merupakan faktor dalam pertumbuhan ekonomi yang menentukan derajat pertumbuhan kemampuan dalam penyediaan berbagai macam barang kepada penduduk. Ketiga, penggunaan teknologi secara luas dan efisien memerlukan adanya penyesuaian di bidang kelembagaan dan ideologi sehingga inovasi yang dihasilkan oleh ilmu pengetahuan dapat dimanfaatkan secara tepat. 
Selanjutnya Boediono (1985: 5) secara singkat mendefinisikan pertumbuhan ekonomi sebagai proses kenaikan output per kapita dalam jangka panjang. Pertumbuhan ekonomi berkaitan dengan kenaikan output/ pendapatan per kapita. Ada dua sisi yang perlu diperhatikan, yaitu output total (Gross Domestic Product/ GDP atau biasa disebut Produk Domestik Bruto/ PDB) dan jumlah penduduk. Output per kapita adalah output total dibagi jumlah penduduk.

Jika disederhanakan pertumbuhan ekonomi terkait dengan peningkatan produksi dan pendapatan masyarakat. Pertumbuhan ekonomi direfleksikan oleh pertumbuhan nilai Produk Domestik Bruto (PDB) atau Produk Domestik Regional Bruto (PDRB) atas dasar harga berlaku (ADHB) atau atas dasar harga konstan (ADHK). Artinya suatu negara atau daerah mengalami pertumbuhan secara ekonomi apabila terjadi peningkatan kapasitas produksi dari semua unit kegiatan ekonomi dalam wilayahnya secara terukur. Pertumbuhan ekonomi yang positif menunjukkan adanya peningkatan kinerja perekonomian dan pertumbuhan ekonomi yang negatif menunjukkan terjadinya penurunan kinerja perekonomian pada negara atau daerah tersebut dibandingkan dengan periode sebelumnya.

\section{Metode Penelitian}

Penelitian ini menggunakan metode penelitian kualitatif untuk membahas dan mengungkapkan masalah penelitian secara mendalam, dan membandingkan temuan di lapangan. Dengan begitu dapat mengungkap bagaimana kapabilitas pemerintah Provinsi Kepulauan Riau dalam pencapaian pertumbuhan ekonomi tahun 2012-2017. Objek dalam penelitian ini adalah kapabilitas pemerintah Provinsi Kepulauan Riau dan pertumbuhan ekonomi Provinsi Kepulauan Riau. Objek penelitian ini diungkap dan dibahas menurut model dynamic governance.

Teknik pengumpulan data melalui wawancara dengan informan yang ditentukan menggunakan teknik purposive sampling (kepala daerah, pejabat pada Organisasi Perangkat Daerah (OPD) terkait, akademisi, dan pihak swasta), observasi di lapangan sesuai dengan obyek yang diteliti, dan studi kepustakaan untuk mengutip, mendeskripsikan dan menelaah berbagai informasi aktual terkait dengan obyek dan lokus penelitian. Kemudian dalam menganalisa data peneliti mengacu pada langkahlangkah meliputi: reduksi data; penyajian data; dan penarikan kesimpulan. Untuk menilai keakuratan hasil penelitian, maka peneliti melakukan validasi data melalui triangulasi data yaitu cross-check dengan cara menanyakan ulang tentang fokus yang sama pada informan yang berbeda-beda untuk menemukan jawaban atau informasi yang benar-benar valid dan juga dilakukan dengan membandingkan jawaban informan dengan data yang tersedia di dokumen dan observasi yang dilakukan. 
154| Donie Tuah F. Kapabilitas Dynamic...

\section{Pembahasan}

Pertumbuhan ekonomi dimaknai dari dua sisi, positif dan negatif. Bermakna positif, jika pertumbuhan ekonomi dapat memberikan kontribusi nyata terhadap peningkatan kualitas hidup dan distribusi pendapatan masyarakat. Bermakna negatif, jika pertumbuhan ekonomi menyebabkan munculnya konsumerisme masyarakat, kerusakan lingkungan, ketidakadilan atau ketimpangan ekonomi. Negara Indonesia menganut paham ekonomi Pancasila dimana negara menguasai segala potensi yang dimiliki untuk mensejahterakan masyarakat sesuai dengan amanat UUD 1945 pasal 33. Oleh karena itu perekonomian tidak boleh diserahkan seluruhnya kepada mekanisme pasar. Sebab, pasar bukanlah sosok yang sempurna. Pasar memiliki berbagai kelemahan, diantaranya pasar tidak bisa menyediakan barang dan jasa publik, pasar tidak bisa mengatasi sentimen negatif yang ditimbulkan oleh aktivitas ekonomi produktif. Untuk itu, pemerintah berkewajiban terlibat dan mengintervensi perekonomian melalui berbagai kebijakan, seperti kebijakan fiskal dan moneter, kebijakan pengentasan kemiskinan, dan lain-lain.

Pertumbuhan ekonomi merupakan target pembangunan yang ingin dicapai oleh pemerintah. Laju dan kualitas pertumbuhan ekonomi juga menjadi indikator keberhasilan pembangunan dan evaluasi kinerja perekonomian dalam rangka meningkatkan kesejahteraan masyarakat. Penurunan pertumbuhan ekonomi yang terjadi di Provinsi Kepulauan Riau tahun 2012-217, membuat beberapa kalangan mempertanyakan kinerja perekonomian daerah. Bagaimana kapabilitas pemerintah dalam merespon gejala-gejala penurunan pertumbuhan ekonomi dan upaya apa yang dilakukan pemerintah daerah, terutama Pemerintah Provinsi Kepulauan Riau dalam meningkatkan perekonomian daerah.

Institusi pemerintahan berpengaruh terhadap pembangunan ekonomi pada sebuah negara atau daerah. Hal ini ditentukan bagaimana interaksi pemerintah dengan rakyatnya dalam memfasilitasi atau justu menghambat pertumbuhan dan pembangunan ekonomi. Hambatan ini dapat muncul ketika pemerintah dianggap tidak terbiasa dengan kompetisi pasar dalam memproduksi barang dan jasa, dan juga kecepatan swasta dalam merespon pasar tidak diiringi oleh pemerintah. Pemerintah dianggap terlambat untuk merespon perubahan yang terjadi. Jadi sebuah kewajaran, apabila rakyat mengehendaki dan berharap pemerintah memiliki kualitas yang baik, cepat, kreatif dan responsif untuk mewujudkan pembangunan ekonomi.

Pemerintah harus bersifat dinamis terhadap berbagai situasi yang terjadi. Pemerintah harus mampu membuka diri melihat perkembangan yang terjadi. Karena sesungguhnya tantangan itu sendiri bersifat dinamis, dipengaruhi oleh banyak keputusan yang terintegrasikan, melibatkan proses adaptasi yang berkelanjutan dan secara 
bertahap, serta membutuhkan implementasi yang tepat. Perlu diingat bahwa keberhasilan sebuah negara/ daerah dapat diukur melalui kualitas pemerintahannya.

Kata kunci dalam pelaksanana dynamic governance adalah adanya perubahan yang terjadi dalam internal pemerintah itu sendiri sebagai aktor dominan dalam governance yang mampu menghasilkan sebuah kebijakan adaptif yang didasarkan pada kemampunan berpikir ke depan (thinking ahead), berpikir kembali (thinking again), dan berpikir lintas batas (thinking across). Untuk dapat menyesuaikan cara yang ditempuh pemerintah dalam menghadapi berbagai dinamika perubahan yang terjadi, maka diperlukan berbagai gerakan perubahan baik dari aspek perencanaan maupun pelaksanaannya. Gerakan perubahan tersebut harus didukung oleh kemampuan aparatur pemerintah dan sistem yang mampu dengan cepat merespon. Di mana keduanya memberikan andil terciptanya kapabilitas pemerintahan yang mampu menghasilkan kebijakan adaptif sesuai dengan dinamika perubahan yang terjadi.

Seperti yang telah dipaparkan di atas bagaimana kondisi perekonomian Provinsi Kepulauan Riau yang sedang dalam kondisi tidak baik, dengan berbagai penyebab terjadinya, menuntut pemerintah untuk segera bertindak untuk mengatasi persoalan tersebut. Kebijakan-kebijakan adaptif sangat diperlukan untuk merespon segala kemungkinan perubahan terkait dengan permasalahan ekonomi yang terjadi. Penyelesaian masalah perekonomian ini merupakan tanggungjawab bersama baik pemerintah pusat maupun daerah. Namun dalam penelitian ini, peneliti hanya membatasi pada apa yang menjadi kewenangan Pemerintah Provinsi Kepulauan Riau dengan menganalisa berdasarkan kapabilitas dynamic governance yang mencakup kemampuan berpikir ke depan (thinking ahead), berpikir kembali (thingking again), dan berpikir lintas batas (thinking across) dan didukung oleh orang yang berkemampuan (able people), proses yang tangkas atau cepat (agile process), dan budaya (Culture).

\section{A. Thinking Ahead}

Kemampuan thinking ahead mendorong pemerintah untuk menganalisa kondisi di masa depan yang penuh ketidakpastiaan dari lingkungan eksternal dengan melihat peluang-peluang baru dan potensi ancaman yang ada. Pemerintah Provinsi Kepulauan Riau seharusnya mampu memprediksi perkembangan perekonomian di masa depan. Dengan begitu pemerintah Provinsi Kepulauan Riau dapat menyiapkan diri untuk mengambil kebijakan dalam menghadapi kemungkinan-kemungkinan yang terjadi. Dalam merespon kondisi pertumbuhan ekonomi yang trennya menurun sejak tahun 2012 hingga 2017. Pemerintah Provinsi Kepulauan Riau telah membuat berbagai kebijakan adaptif yang didasarkan pada kemampuan thinking ahead yaitu: pengembangan sektor pariwisata dan kebijakan pengentasan kemiskinan. 
156| Donie Tuah F. Kapabilitas Dynamic...

\section{Pengembangan Sektor Pariwisata}

Luas wilayah laut Provinsi Kepulauan Riau yang mencapai 98\% (RPJMD Provinsi Kepulauan Riau Tahun 2016-2021), sudah selayaknya pemerintah daerah harus lebih memperhatikan pengembangan sektor maritim, di mana salah satunya ialah pariwisata. Provinsi Kepulauan Riau memiliki potensi yang besar dalam sektor pariwisata. Letak geografis yang strategis berbatasan langsung dengan beberapa negara tetangga dan ditambah dengan keindahan alam, khususnya laut menjadi modal tersendiri. Selain itu, sektor pariwisata juga tidak terpengaruh besar dengan kondisi perekonomian global. Jadi sektor ini dapat menjadi salah satu motor penggerak perekonomian daerah. Pembangunan sektor pariwisata dapat dikembangkan di semua kabupaten/ kota, tidak bertumpu di salah satu kabupaten/ kota seperti halnya sektor industri pengolahan dan konstruksi yang dominan berada di Kota Batam serta sektor pertambangan dan penggalian yang dominan di Kabupaten Natuna dan Kabupaten Kepulauan Anambas.

Komitmen pemerintah Provinsi Kepulauan Riau dalam pembangunan sektor pariwisata sebagai salah satu sektor unggulan yang mampu meningkatkan pertumbuhan ekonomi dituangkan dalam sebuah rencana besar pembangunan pariwisata daerah berupa Peraturan Daerah No. 5 Tahun 2012 tentang Rencana Induk Pembangunan Kepariwisataan Daerah (RIPPDA) tahun 2012-2022. Pembangunan pariwisata yang difokuskan dalam RIPPDA ialah: Pertama, pembangunan destinasi pariwisata yang bertujuan untuk meningkatkan kualitas dan kuantitas daya tarik sehingga mampu mewujudkan destinasi pariwisata yang bersaing di pasar nasional dan internasional yang dapat memberikan dampak positif bagi peningkatan perekonomian masyarakat. Pemerintah Provinsi Kepulauan Riau telah menetapkan Koridor Pariwisata Daerah (KPD) berdasarkan keunggulan komparatif yang dimiliki oleh kabupaten/ kota, yaitu:

1. Pengembangan KPD Batam sebagai kawasan Wisata Kota, Wisata Bahari dan Wisata MICES (meeting, incentive, convention, exhibition, and sports);

2. Pengembangan KPD Bintan sebagai kawasan Wisata Terpadu Eksklusif, Kawasan Wisata Terbuka Umum, dan Wisata Minat Khusus;

3. Pengembangan KPD Karimun sebagai kawasan Wisata Alam, Wisata Minat Khusus dan Wisata Agro;

4. Pengembangan KPD Tanjungpinang sebagai kawasan Wisata Sejarah, Wisata Budaya dan Wisata Kreatif;

5. Pengembangan KPD Natuna sebagai kawasan Wisata Bahari, Minat Khusus dan Ekowisata;

6. Pengembangan KPD Anambas sebagai kawasan Wisata Bahari dan Ekowisata; dan

7. Pengembangan KPD Lingga sebagai kawasan Wisata Sejarah, Wisata Budaya, Wisata Alam dan Wisata Bahari. 
Kedua, pembangunan pemasaran pariwisata untuk mempromosikan produkproduk pariwisata di Provinsi Kepulauan Riau baik di dalam maupun luar negeri sehingga meningkatkan jumlah kunjungan wisatawan. Memaksimalkan kinerja pemasaran pariwisata melalui media pemasaran inovatif dan interaktif baik konvensional (pameran/ event promosi wisata) maupun digital (media elektronik, media sosial). Ketiga, pembangunan industri pariwisata yang mampu mewujudkan industri pariwisata sebagai penggerak perekonomian daerah. Industri pariwisata terkait dengan segala jenis usaha yang berkaitan dengan pemenuhan kebutuhan wisatawan, seperti akomodasi penginapan; transportasi; kuliner; biro perjalanan; pertunjukkan seni dan budaya; event olahraga, dan lain-lain.

Keempat, pembangunan kelembagaan pariwisata untuk meningkatkan peran aktif dari stakeholder pariwisata dan meningkatkan kualitas dan kuantitas SDM pelaku pariwisata agar dapat memberikan nilai tambah pada kualitas daya tarik destinasi wisata. Selain itu program ini juga bertujuan mewujudkan tata kelola pariwisata yang mampu mensinergikan ketiga program lainnya secara profesional, efektif dan efisen. Pemerintah Provinsi Kepulauan Riau terus mendorong tumbuhnya kelompok sadar wisata (Pokdarwis) di kabupaten/ kota. Kelompok ini sebagai bentuk partisipasi dan dukungan para pemangku kepentingan dalam mendorong iklim yang kondusif bagi tumbuh dan berkembangnya pariwisata. Selain itu pemerintah Provinsi Kepulauan Riau juga mendorong generasi pesona Indonesia (Genpi) sebagai komunitas yang memiliki peran penting dalam mempromosikan pariwisata daerah melalui media sosial. Kemudian dalam Rencana Pembangunan Jangka Menengah Daerah (RPJMD) Provinsi Kepulauan Riau tahun 2016-2021, program prioritas pembangunan pariwisata ditambahkan dengan program pembangunan ekonomi kreatif. Sebagai bentuk respon pemerintah terhadap perkembangan terkini, di mana ekonomi kreatif menjadi sebuah inovasi baru dalam sektor pariwisata.

Pemerintah Provinsi Kepulauan Riau menyadari bahwa kebijakan pembangunan sektor pariwisata bukanlah sebuah kebijakan yang diambil untuk jangka pendek, kebijakan ini akan terus berkembang dan berkelanjutan. Kebijakan ini menjadi peluang bagi daerah untuk membangun perekonomiannya melalui suatu pola kebijakan yang terintegrasi. Pariwisata perlu didukung oleh sektor-sektor lainnya, seperti: infrastruktur, budaya, pendidikan, keamanan, dan lain-lain.

Komitmen dan konsistensi pemerintah Provinsi Kepulauan Riau dengan dukungan pemerintah pusat dan pemerintah kabupaten/ kota serta stakeholder terkait sangat diperlukan. Karena pembangunan sektor pariwisata bukan hanya untuk kepentingan pemerintah daerah sebagai peluang untuk pemenuhan sumber pendapatan asli daerah semata. Melainkan peluang tersebut mengandung terbukanya pembangunan ekonomi daerah. Sektor pariwisata dapat dikatakan sebagai media pembangunan ekonomi yang 
tidak memerlukan investasi terlalu besar dalam jangka panjang sebelum memberikan keuntungan. Sektor pariwisata dapat mengurangi ketergantungan impor karena sebagian besar barang modal dan barang habis pakai dapat disediakan oleh destinasi wisata seperti: kerajinan, makanan dan minuman, dan daya tarik wisata (Antariksa, 2016: 35-36).

Pembangunan sektor pariwisata dapat memberikan multiplier effect bagi berkembangnya kegiatan atau usaha-usaha lainnya yang berkaitan dengan pariwisata, seperti industri kerajinan, makanan/ kuliner dan lain-lain. Dengan berkembangnya pariwisata maka akan semakin banyak wisatawan baik lokal maupun mancanegara yang datang berkunjung sehingga pada akhirnya akan meningkatkan perluasan kesempatan kerja dan berusaha, meningkatkan pendapatan masyarakat, meningkatnya kesejahteraan masyarakat, serta dapat menumbuhkan pertumbuhan ekonomi.

Dari data Badan Pusat Statistik (BPS) Provinsi Kepulauan Riau tahun 2018, menunjukkan bahwa jumlah kunjungan wisatawan mancanegara ke Provinsi Kepulauan Riau meningkat dari sebelumnya pada tahun 2012 sebanyak 1.767 .439 orang menjadi 2.074.534 orang di tahun 2017, meningkat hingga 17,38\%. Jumlah wisatawan mancangera yang berkunjung ke Provinsi Kepulauan Riau menduduki peringkat 3 (tiga) secara nasional di bawah Povinsi Bali dan Jakarta. Jumlah kunjungan ini berkontribusi sebesar $14,77 \%$ terhadap jumlah kunjungan wisatawan mancanegara secara nasional di tahun 2017 (Dinas Pariwisata Provinsi Kepulauan Riau, 2019).

Jumlah kunjungan wisatawan nusantara juga menunjukkan peningkatan dari tahun ke tahun. Di tahun 2012 wisatawan nusantara yang berkunjung ke Provinsi Kepulauan Riau berjumlah 1.431.864 orang meningkat 147,79\% di tahun 2017 menjadi 3.547.971 orang (Dinas Pariwisata Provinsi Kepulauan Riau, 2019). Namun dengan jumlah kunjungan yang cukup besar tersebut, ternyata rata-rata lama menginap wisatawan di Provinsi Kepulauan Riau hanya 1,78 hari (BPS Provinsi Kepulauan Riau, 2018). Tentu ini berpengaruh terhadap target ekonomi dari sektor pariwisata yang diharapkan memberikan kontribusi lebih terhadap perekonomian daerah. Sebagai sektor yang menjadi prioritas pembangunan ekonomi untuk pencapain pertumbuhan ekonomi yang tinggi. Faktanya sektor pariwisata hanya berkontribusi sebesar 1,8\% hingga 2,3\% terhadap PDRB Provinsi Kepulauan Riau (Dinas Pariwisata Provinsi Kepulauan Riau, 2019).

Terlepas dari masih kecilnya kontribusi sektor pariwisata terhadap PDRB Provinsi Kepulauan Riau. Perlu digarisbawahi bahwa pembangunan sektor pariwisata bukan hanya soal produk pariwisatanya saja, melainkan adanya keterlibatan berbagai macam bidang yang tentu membutuhkan koordinasi dan kolaborasi untuk menyatukan visi yang sama dari berbagai stakeholder yang berkepentingan. Karena jika tolak ukur keberhasilan sektor pariwisata hanya berbicara tentang meningkatnya jumlah kunjungan 
wisatawan dan seberapa besar devisa atau uang yang diterima. Maka tak ubahnya pemerintah daerah seperti sebuah perusahaan jasa pariwisata yang hanya mencari keuntungan secara ekonomis. Pemerintah daerah harus memahami bahwa kebijakan sektor pariwisata yang baik adalah yang menyangkut kepentingan publik lebih luas, tidak hanya kepada kalangan bisnis tertentu sehingga evaluasi mengenai dampaknya secara komperehensif terhadap kehidupan masyarakat juga menjadi isu yang penting.

Dengan kebijakan Rencana Induk Pembangunan Kepariwisataan Daerah (RIPPDA), pemerintah Provinsi Kepulauan Riau telah memiliki visi ke depan untuk menjadikan sektor pariwisata sebagai sektor unggulan yang mampu menggerakkan pembangunan ekonomi. Pembangunan pariwisata juga didasarkan pada Rencana Tata Ruang Wilayah (RTRW) Provinsi Kepulauan Riau. Dengan begitu pembangunan pariwisata sesuai dengan sistem tata ruang yang menjadi pedoman pembentukan sistem pariwisata yang terpadu dalam konteks perwilayahan.

\section{Program Pengentasan Kemiskinan}

Seperti yang telah disinggung di atas, bahwa dalam konteks pembangunan ekonomi Pemerintah Provinsi Kepulauan Riau tidak hanya pro bisnis tetapi juga pro masyarakat sebagai bagian dari pelaku aktivitas ekonomi. Pertumbuhan ekonomi berpengaruh kepada kesejahteraan masyarakat, begitu juga sebaliknya kesejahteraan masyarakat mampu memacu pertumbuhan ekonomi melalui konsumsi rumah tangga, investasi, dan sumberdaya manusia. Oleh karena itu Pemerintah Provinsi Kepulauan Riau menginisiasi sebuah program pengentasan kemiskinan yang dituangkan ke dalam Nota Kesepahaman bersama dengan pemerintah Kabupaten/ Kota.

Kesepakatan ini bertujuan untuk menyelaraskan pelaksanaan program atau kegiatan pengentasan kemiskinan dengan sasaran berkurangnya jumlah penduduk miskin dan berkurangnya jumlah desa tertinggal di Provinsi Kepulauan Riau. Nota kesepahaman bersama ini dilaksanakan selama 5 (lima) tahun sejak 2010. Sedangkan pembiayaan program ini bersumber dari APBD Kabupaten/ Kota dan APBD Provinsi Kepulauan Riau dengan perbandingan satu banding dua. Jadi anggaran yang bersumber dari APBD Provinsi Kepulauan Riau dua kali lipat dari jumlah anggaran yang bersumber dari ABPD Kabupaten/ Kota. Kebijakan ini menunjukkan komitmen Pemerintah Provinsi Kepulauan Riau untuk mendorong pembangunan ekonomi yang berkualitas dan merata.

Adapun Program pengentasan kemiskinan tersebut terdiri dari 3 (tiga) program (Pergub No. 1 tahun 2012 tentang Program Pengentasan Kemiskinan Provinsi Kepulauan Riau), yaitu:

1. Program pemenuhan hak-hak dasar penduduk miskin terdiri dari 5 (lima) kegiatan, yaitu : 
160| Donie Tuah F. Kapabilitas Dynamic...

a. Pemberian makanan tambahan balita/ anak sekolah bagi penduduk miskin/ desa tertinggal;

b. Perawatan kasus gizi buruk/ gizi kurang bagi penduduk miskin/ desa tertinggal;

c. Pelayanan kesehatan bagi penduduk miskin/ desa tertinggal melalui Jaminan Kesehatan Daerah (JAMKESDA);

d. Pembangunan/ rehabilitasi posyandu, puskesmas pembantu dan puskesdes;

e. Pemberian beasiswa bagi siswa SMA dari keluarga miskin/ desa tertinggal.

2. Program rumah layak huni terdiri dari 3 (tiga) kegiatan, yaitu :

a. Rehabilitasi rumah tidak layak huni termasuk fasilitas jamban keluarga;

b. Penyediaan sarana lingkungan dan sumber air bersih penduduk miskin/ desa tertinggal;

c. Penyediaan listrik rumah penduduk miskin/ desa tertinggal.

3. Program pembinaan unit usaha penduduk miskin/ desa tertinggal terdiri dari 3 (tiga) kegiatan, yaitu :

a. Kegiatan menumbuh kembangkan Kelompok Usaha Bersama (KUBE) dan Koperasi, Usaha Kecil dan Menengah, diutamakan bagi ibu-ibu/ perempuan pada penduduk miskin/ desa tertinggal;

b. Kegiatan menumbuh kembangkan usaha nelayan, pembudidaya ikan dan keluarga pengolah hasil perikanan serta motorisasi perikanan tangkap penduduk miskin/ desa tertinggal;

c. Kegiatan menumbuh kembangkan usaha pertanian bagi penduduk miskin/ desa tertinggal.

Program pengentasan kemiskinan ini dapat dikatakan cukup berhasil dalam mengurangi jumlah penduduk miskin di Provinsi Kepulauan Riau. Di akhir tahun pelaksanaan kebijakan ini angka kemiskinan jauh menurun dibanding dengan tahuntahun sebelumnya, yaitu sebesar 5,78\% dengan jumlah penduduk miskin 114,83 ribu jiwa (BPS Provinsi Kepulauan Riau, 2018). Namun sangat disayangkan nota kesepahaman bersama ini tidak dilanjutkan kembali setelah masa berlakunya selesai di tahun 2015. Padahal program ini sangat berdampak langsung kepada masyarakat. Masyarakat penerima bantuan ini dapat merubah kehidupan ekonominya menjadi lebih baik.

\section{B. Thinking Again}

Kemampuan thinking again mendorong pemerintah untuk mengevaluasi dan mengidentifikasi perubahan kebijakan yang telah ditetapkan agar memperoleh hasil dan kualitas yang lebih baik. Dinamisnya peraturan perundang-undangan harus segera direspon oleh pemerintah Provinsi Kepulauan Riau dengan mengevaluasi segala kebijakan yang sudah tidak sesuai lagi dengan kondisi yang ada. Pemerintah juga harus 
memiliki sikap terbuka dari berbagai kritikan yang mengarah padanya terkait dengan kebijakan-kebijakan yang diambil. Terkadang sebuah kebijakan tidak sesuai antara apa yang direncanakan dengan apa yang didapatkan setelah diimplementasikan. Pemerintah harus mengevaluasi berbagai kebijakan yang kurang mendapat respon atau bahkan mendapat respon negatif dari masyarakat. Ada tiga kebijakan adaptif yang merupakan hasil analisa dari kemampuan thinking again yang dilakukan oleh Pemerintah Provinsi Kepulauan Riau, yaitu: kebijakan poros maritim Indonesia, pendirian PT. Pelabuhan Kepri, dan pengembangan E-government.

\section{Poros Maritim Indonesia}

Visi Provinsi Kepulauan Riau 2016-2021 sedikit berbeda dengan visi-visi sebelumnya, yaitu adanya penambahan visi untuk mewujudkan Kepulauan Riau "unggul di bidang maritim". Tentunya ini bukanlah hanya sekedar ingin berbeda saja. Namun ini merupakan sebuah visi yang harus dimaknai sebagai perubahan orientasi pembangunan Provinsi Kepulauan Riau. Pada periode sebelumnya memang sudah ada pembangunan berbasis maritim, namun belum terintegrasi, masih bersifat parsial hingga pada akhirnya keunggulan potensi maritim yang dimiliki belum dapat berkontribusi besar terhadap pembangunan daerah. Bahkan sebenarnya konsep pembangunan maritim ini sudah ada sejak dulu. Sejarah menyebutkan bahwa pusat-pusat perekonomian pada zaman kerjaaan Riau Lingga itu berada di pesisir pantai dan laut.

Dengan adanya kemauan politik yang kuat dari gubernur dan wakil gubernur melalui visi misinya dan diterjemahkan ke dalam Rencana Pembangunan Jangka Menengah Daerah (RPJMD) Provinsi Kepulauan Riau tahun 2016-2021, maka kemaritiman menjadi orientasi utama pembangunan yang dilakukan di Provinsi Kepulauan Riau. Visi "unggul di bidang maritim" ini selaras dengan kebijakan pembangunan nasional, yang ingin menjadikan Indonesia sebagai poros maritim dunia. Unggul di bidang maritim diartikan bahwa Provinsi Kepulauan Riau dicita-citakan memiliki keunggulan pada sektor kemaritiman terutama sektor kelautan dan perikanan, perhubungan, dan pariwisata didukung dengan pembangunan sektor-sektor lainnya. Tujuan pembangunan kemaritiman dalam RPJMD Provinsi Kepulauan Riau tahun 20162021, yaitu:

a. Meningkatkan kesejahteraan masyarakat, khususnya nelayan dan pembudidaya ikan;

b. Menghasilkan produk dan jasa kelautan yang berdaya saing tinggi;

c. Meningkatkan kontribusi sektor kelautan bagi perekonomian daerah;

d. Menciptakan lapangan kerja;

e. Meningkatkan konsumsi ikan;

f. Memelihara daya dukung lingkungan dan kelestarian sumberdaya kelautan. 
162| Donie Tuah F. Kapabilitas Dynamic...

Visi unggul di bidang maritim ini memberikan penegasan bahwa Provinsi Kepulauan Riau sebagai daerah berciri maritim yang dapat menjadi penopang utama mimpi Indonesia ke depan sebagai poros maritim dunia. Provinsi Kepulauan Riau yang memiliki potensi kemaritiman yang sangat kaya dan ditambah dengan beberapa daerah di Provinsi Kepulauan Riau yang memiliki keistimewaan Free Trade Zone (FTZ) yang mampu mendukung industri kemaritiman. Di mana keunggulan FTZ ini menunjukkan kesiapan Provinsi Kepulauan Riau dibandingkan daerah maritim lainnya. Maka tidak ada salahnya jika Provinsi Kepuluan Riau memiliki mimpi untuk menjadikan daerahnya sebagai poros maritim Indonesia.

Provinsi Kepulauan Riau memiliki empat potensi kemaritiman yang dapat dikembangkan, yaitu sumberdaya kelautan dan perikanan, jasa transportasi pelayaran dan perdagangan, wisata bahari, dan energi berkelanjutan. Upaya pemerintah Provinsi Kepulauan Riau untuk memaksimalkan kontribusi sektor maritim dalam membangun perekonomian daerah melalui berbagai program (Barenlitbang Provinsi Kepulauan Riau, 2018): Pertama, pengelolaan sumberdaya kelautan dan perikanan berbasis masyarakat yang lebih memprioritaskan perikanan budidaya dibanding dengan perikanan tangkap guna keberlanjutan pemanfaatan potensi ini. Kedua, mendorong peningkatan investasi kelautan dan perikanan. Investasi bisa berupa pembangunan pabrik dan cold storage, dan pabrik pengalengan ikan. Juga investasi ilmu pengetahuan berupa pengembangan inovasi teknologi guna meningkatkan hasil produksi dan daya saing produk kelautan dan perikanan. Pemerintah Provinsi Kepulauan Riau berkolaborasi dengan pihak industri, akademisi dan masyarakat membentuk pola-pola kemitraan untuk mendorong kualitas produk kelautan dan perikanan melalui berbagai inovasi teknologi.

Ketiga, peningkatan industri maritim. Industri maritim diantaranya mencakup industri pengilangan minyak bumi dan LNG (Liquefied Natural Gas) serta industri yang menunjang kegiatan ekonomi di pesisir dan laut, yaitu industri galangan kapal (shipyard), dan jasa perbaikan kapal (docking). Keempat, pemanfaatan perairan laut untuk kegiatan jasa kelautan seperti labuh jangkar kapal. Sebagai jalur lalu lintas perdagangan internasional, perairan Kepulauan Riau memiliki potensi sebagai tempat parkir kapal. Kelima, pembangunan konektivitas antar pulau dan antar kabupaten/ kota guna mendukung pemerataan pembangunan. Kepulauan riau yang terdiri dari 1.796 pulau dan tersebar membutuhkan transportasi laut untuk mobiltas orang dan barang antar pulau. Pembangunan konektivitas yang dilakukan pemerintah Provinsi Kepulauan Riau melalui program peningkatan pelayanan angkutan laut dan pembangunan transportasi laut berupa pembangunan pelabuhan dan dermaga, dan penyediaan kapal. Keenam, pemanfaatan potensi wilayah pesisir dan pulau-pulau kecil untuk pengembangan pariwisata bahari. Provinsi Kepulauan Riau memiliki potensi wisata bahari yang besar. Berbagai daya tarik wisata yang dapat dikembangkan ialah pantai, 
keragaman biota laut, wisata budaya, dan olahraga. Pengembangan potensi wisata bahari yang dilakukan pemerintah Provinsi Kepulauan Riau melalui program-program dalam Rencana Induk Pembangunan Kepariwisataan Daerah yang telah dijelaskan di atas.

Reorientasi kebijakan pembangunan daerah menuju pengembangan perekonomian maritim membawa pergeseran paradigma pembangunan wilayah maritim terintegrasi dengan pembangunan wilayah darat. Jadi inti pembangunan di daerah bertumpu pada pengembangan wilayah maritim. Pembangunan wilayah maritim akan membantu peningkatan aktivitas perekonomian di wilayah darat. Sehingga secara bertahap akan meningkatkan kesejahteraan masyarakat khususnya masyarakat di wilayah pesisir.

\section{Pendirian PT. Pelabuhan Kepri}

PT. Pelabuhan Kepri ialah Badan Usaha Milik Daerah (BUMD) Provinsi Kepulauan Riau yang didirikan pada tahun 2014 berdasarkan Peraturan Daerah No. 2 Tahun 2013 tentang Pembentukan Badan Usaha Pelabuhan (BUP) PT. Pelabuhan Kepri. Pendirian BUMD ini bentuk peran pemerintah sebagai entrepreneur dalam perekonomian daerah. Selain itu, pendirian BUMD ini juga sebagai alternatif usaha, mengingat 2 (dua) BUMD lainnya yang telah beroperasi yaitu PT. Pembangunan Kepri dan PDAM Tirta Kepri belum memberikan kontribusi terhadap pendapatan asli daerah (PAD).

Bidang usaha kedua BUMD tersebut juga belum menyangkut dengan pengelolaan potensi maritim yang dimiliki Provinsi Kepulauan Riau. Oleh karena itu pemerintah menganggap bahwa pendirian PT. Pelabuhan Kepri ini sebagai peluang besar untuk bisa memanfaatkan potensi maritim daerah. PT. Pelabuhan Kepri didirikan untuk mengelola dan memanfaatkan perairan Kepulauan Riau, termasuk potensi alam dan geografis wilayah dan serta mengembangkan industri pelabuhan dan kepelabuhan yang terkait dengan transportasi laut dan antarmoda lainnya. Tentunya dengan pendirian ini diharapakan mampu membuka lapangan kerja, menstimulus peluang kegiatan usaha pendukungnya, peningkatan penguasaan teknologi modern dalam layanan pelabuhan dan kepelabuhan. Selain itu yang terpenting ialah mampu berkontribusi bagi perekonomian daerah dan meningkatkan pendapatan asli daerah (PAD).

Dalam perjalanannya sejak tahun 2014 hingga sekarang PT. Pelabuhan Kepri hanya menjalankan dua bidang usaha. Pertama, transportasi laut dengan menyediakan Kapal Mv. Lintas Kepri bersubsidi untuk menjangkau daerah-daerah yang tidak dilalui oleh kapal komersial lainnya. Keberadaanya sangat membantu untuk mobilitas orang dan barang antar pulau yang selama ini sulit dijangkau. Namun sayangnya kapal yang 
164| Donie Tuah F. Kapabilitas Dynamic...

dimiliki hanya satu, sehingga belum dapat memenuhi harapan masyarakat kepulauan yang sangat tergantung pada transportasi laut. Kedua, usaha labuh jangkar yang sebenarnya menjadi suatu harapan baru bagi peningkatan PAD, karena banyaknya kapal-kapal yang berlabuh di perairan Kepulauan Riau. Namun faktanya juga masih jauh dari harapan, pemerintah pusat masih enggan untuk melepas pengelolaan labuh jangkar kepada pemerintah daerah. Sehingga sewa labuh jangkar belum dapat dipungut oleh daerah. Padahal secara aturan dalam Undang-Undang 23 tahun 2014 tentang Pemerintah Daerah, pemerintah Provinsi Kepulauan Riau memiliki hak dan kewenangan untuk mengelola daerah perairan 0-12 mil dari bibir pantai.

Selain itu kondisi internal PT. Pelabuhan Kepri juga turut mempengaruhi kinerja BUMD ini. Permasalahannya ialah kompetensi sumberdaya manusia BUMD yang masih minim; konflik kepentingan di internal BUMD; dan penunjukkan Direksi yang belum mengarah pada profesionalitas, dan masih bermuatan politis. Hal ini sangat disayangkan, mengingat bahwa pemerintah Provinsi Kepulauan Riau telah menggelontorkan penyertaan modal sebesar Rp. 25 Milyar kepada PT. Pelabuhan Kepri sejak tahun 2014. Di tengah harapan akan kebermanfaatan BUMD ini, faktanya di internal BUMD malah terus berpolemik sehingga kinerjanya tidak optimal. Selain itu tidak ada ketegasan dari pemerintah Provinsi Kepulauan Riau, khususnya gubernur melihat kondisi kinerja BUMD ini. Seharusnya gubernur bersikap lebih tegas terhadap kinerja BUMD ini, dan terus melakukan evaluasi. Gubernur memiliki kewenangan untuk menegur bahkan memberhentikan para direksi apabila dianggap tidak mampu.

\section{Pengembangan E-Government}

Salah satu upaya untuk mewujudkan pemerintahan yang berdaya saing tinggi dan mampu memanajemen perubahan adalah mempercepat proses kerja serta modernisasi penyelenggaraan pelayanan kepada masyarakat melalui e-government. Egovernment merupakan tuntutan yang berkembang saat ini dan kebutuhan yang sangat mendesak. Di mana pemerintah dituntut untuk bekerja lebih efekif, efisien, responsif, transparan, dan bersih. E-government diperuntukkan untuk memangkas proses birokrasi, sebagai bentuk transparansi kepada masyarakat, alat kontrol sosial terhadap program-program kerja pemerintah, dan meminimalisir terjadinya penyalahgunaan kewenangan dan anggaran. Dengan kata lain e-government mengubah cara masyarakat berinteraksi dengan pemerintah dan cara pemerintah mengelola tugas dan pekerjaannya sehari-hari guna mewujudkan tata kelola pemerintahan yang baik, yang tentunya akan berdampak pada pembangunan ekonomi daerah.

Gagasan e-government sebenarnya sudah lama digaungkan. Di mana pemerintah telah mengeluarkan Instruksi Presiden No. 3 Tahun 2003 tentang Kebijakan dan Strategi Nasional Pengembangan E-government. E-government tersebut merupakan upaya untuk 
mengembangkan penyelenggaraan pemerintahan yang berbasis elektronik dalam rangka meningkatkan kualitas layanan publik secara efektif dan efisien. Selanjutnya, Pemerintah Provinsi Kepulauan Riau juga turut mengembangkan e-government dalam mendukung penyelenggaraan pemerintahan yang profesional. Awal perintisannya dimulai sejak periode gubernur pertama $\mathrm{H}$. Ismeth Abdullah yang meluncurkan website resmi pemerintah Provinsi Kepulauan Riau www.kepriprov.go.id dan website-website OPD sebagai media informasi kegiatan-kegiatan yang dilakukan pemerintah, belum pada pelayanan kepada masyarakat.

Kemudian dilanjutkan pada periode gubernur kedua H. Muhammad Sani yang menginisiasi Layanan Pengadaan Secara Elektronik (LPSE) untuk meminimalisir praktikpratik korupsi dalam pengadaan barang dan jasa di Provinsi Kepulauan Riau. Juga ada beberapa aplikasi penunjang kinerja internal pemerintah, seperti SIMPEG (Sistem Informasi Manajemen Kepegawaian). Namun masih dilakukan dimasing-masing OPD dan belum terintegrasi pada satu data center. Pengembangan e-government terus dilakukan hingga pada tahun 2017 Pemerintah Provinsi Kepulauan Riau menerbitkan Peraturan Gubernur No. 50 tahun 2017 tentang Pelaksanaan dan Pengembangan E-government Provinsi Kepulauan Riau. Dengan Pergub ini setiap aplikasi pendukung e-government dari OPD terintegrasi melalui KIIS (Kepri Integrated Information System) yang berbasis di Dinas Komunikasi dan Informasi. Ke depannya pengintegrasian ini untuk mendukung terwujudnya Kepri Smart Province.

Beberapa aplikasi e-government yang dikembangkan yaitu: (1) E-planning yang dikelola Badan Perencanaan, Penelitan dan Pengembangan (Barenlitbang) merupakan aplikasi untuk penyusunan Rencana Kerja Pemerintah Daerah (RKPD) dan Kebijakan Umum Aggaran (KUA)/ Prioritas dan Plafon Anggaran Sementara (PPAS) dengan mengacu kepada program-program yang telah terdapat pada RPJMD. (2) Sistem Informasi Monitoring Belanja Modal (Sim-Bemo) yang dikelola oleh Badan Pengelolaan Keuangan dan Aset Daerah (BPKAD) merupakan sistem informasi berbasis web yang mampu menyediakan informasi belanja modal secara akurat, cepat, realtime, dan terintegrasi yang dapat dimanfaatkan dalam rangka meningkatkan kualitas pengawalan terhadap belanja modal, melakukan monitoring belanja setiap saat, check and balance dalam laporan keuangan dengan bagian asset, dan sebagai early warning system dalam pengadaan barang/ jasa, dan untuk mengefektifkan pengawasan oleh aparat pengawasan. (3) E-simda yang juga dikelola oleh Badan Pengelolaan Kekayaan dan Aset Daerah (BPKAD) berisikan Dokumen Pelaksanan Anggaran (DPA) dan realisasi OPD. (4) Sistem Informasi Pajak Kendaraan Bermotor (Sipamor) yang dikelola oleh Badan Pengelolaan Pajak dan Retribusi Daerah (BP2RD) merupakan aplikasi yang terintegrasi untuk menangani proses perizinan kepemilikan kendaran bermotor, mulai dari awal pendaftaran kendaraan baru, pembayaran pajak, STNK hingga bea balik nama. Aplikasi 
166| Donie Tuah F. Kapabilitas Dynamic...

ini juga menampilkan data penerimaan pajak kendaraan bermotor secara realtime pada setiap kantor samsat. (5) Sistem Informasi Rencana Umum Pengadaan (Sirup) yang dikelola oleh Biro Administrasi Layanan Pengadaan menampilkan data pelelangan barang dan jasa yang dilakukan secara elektronik. (6) Sistem Informasi Perizinan-PTSP (SIPPTSP) yang dikelola oleh Dinas Penanaman Modal dan Pelayanan Terpadu Satu Pintu (DPMPTSP) untuk memudahkan pelaku usaha mengajukan perizinan untuk usahanya.

Aplikasi e-government tersebut merupakan aplikasi-aplikasi yang mendukung kinerja pemerintah Provinsi Kepulauan Riau dalam pembangunan ekonomi daerah. Dengan e-planning maka program-program pembangunan pemerintah sesuai dengan RPJMD, meminimalisir program-program "titipan" yang sarat akan tindak pindana korupsi. Sim-Bemo, Sirup, dan E-Simda membantu pemerintah untuk bekerja secara transparan dan akuntabel kepada masyarakat, dan juga membantu kinerja pengelolaan keuangan daerah lebih professional dan meminimalisir penyelewengan kewenangan dan anggaran. Sipamor menyediakan data penerimaan pajak kendaraan bermotor secara realtime sehingga membantu pengambilan kebijakan tertentu untuk menjaga stabilitas penerimaan pajak. Terkadang target penerimaan pajak belum tercapai pada tahun berjalan sehingga gubernur mengeluarkan kebijakan berupa insentif pajak kendaraan bermotor untuk mendongkrak penerimaan pajak, seperti pembebasan denda dan bea balik nama.

Terkahir, SIP-PTSP yang tentunya sangat berpengaruh langsung terhadap iklim investasi daerah karena berhubungan langsung dengan kepentingan para pelaku usaha. Dengan PTSP, pemerintah Provinsi Kepulauan Riau telah melakukan pemangkasan struktur, melakukan efisiensi dan mengintegrasikan proses bisnis serta memperpendek rentang kendali dan jarak antara unit layanan dengan masyarakat. Desain PTSP mengintegrasikan sebagian atau seluruh proses pelayanan perizinan/ non perizinan ke satu tempat agar persyaratan, biaya, dan prosedur menjadi lebih singkat dan sederhana tanpa harus menghilangkan prinsip kehati-hatian. Pelaku usaha mendapatkan kemudahan, kepastian, dan kejelasan karena hanya perlu datang kesatu tempat, mulai dari pengajuan permohonan hingga pengambilan surat perizinan. Kemudahan tersebut kini juga didukung dengan penggunan layanan berbasis online SIP-PTSP.

E-government bukan hanya sekedar penggunaan teknologi informasi saja, melainkan juga dikombinasikan dengan perubahan organisasi dan keterampilan baru dalam rangka memperbaiki pelayanan publik dan mendukung kebijakan publik. Membawa perubahan kinerja dari internal pemerintah pada perubahan yang lebih besar berdampak kepada masyarakat. Oleh karena itu, keuntungan yang diperoleh dari egovernment bukan hanya sekedar menyediakan pelayanan berbasis online semata tetapi lebih luas daripada itu, karena kinerja sektor publik juga berkontribusi pada kemajuan pembangunan ekonomi dan sosial. 


\section{Thinking Across}

Kemampuan thinking across mendorong pemerintah untuk dapat melakukan benchmarking to best practice. Di mana cara ini sebagai satu cara memperbaiki kinerja pemerintah dengan mencontoh daerah yang sudah berhasil. Apalagi sekarang sudah banyak daerah yang dapat dijadikan percontohan pada bidang-bidang tertentu. Mengadopsi sebuah inovasi yang dilakukan daerah lain ke daerah sendiri saat ini sangat mudah dilakukan. Kebanyakan daerah yang menjadi percontohan selalu terbuka untuk memberikan ide atau gagasan tersebut. Namun dari hasil observasi dan wawancara di lapangan, peneliti tidak menemukan kebijakan terkait dengan perekonomian daerah yang diadopsi Pemerintah Provinsi Kepulauan Riau. Jadi, peneliti menyimpulkan bahwa sampai dengan penelitian dibuat Pemerintah Provinsi Kepulauan Riau belum ada mengadopsi kebijakan ekonomi dari daerah lain. Namun ke depannya besar kemungkinan Pemerintah Provinsi Kepulauan Riau akan mengadopsi beberapa kebijakan dari daerah lain.

\section{Able People}

Kapasitas terbesar untuk mewujudkan perubahan dalam dynamic governance terletak pada kapabilitas sumberdaya manusia pemerintahan, yaitu para pemimpin dan aparatur yang membantunya. Mereka adalah orang yang memiliki kapasitas untuk dapat berpikir, merasakan, membuat pilihan dan untuk mengembangkan kemampuan aparatur dan organisiasi. Mereka yang memiliki kemampunan unggul inilah yang akan menjadi "detak jantung" dalam mengembangkan kemampuan dynamic governance. Jelas bahwa dalam kapabilitas dynamic governance, yang pertama dan terpenting adalah modal manusia dalam organisasi pemerintah.

Dengan SDM yang mumpuni akan menghasilkan berbagai kebjakan yang baik dan akan memberikan dampak pada peningkatan pertumbuhan ekonomi. Pemerintah harus diisi oleh pejabat-pejabat dan aparatur yang berkualitas, professional dengan tingkat keunggulan kompetitif yang mampu memberikan kontribusi yang optimal bagi penyelenggaran organisasi pemerintah. Penempatan orang-orang pada posisi atau jabatan tertentu harus didasarkan pada pertimbangan kemampuan, keahlian, keterampilan atau kualifikasi tertentu sebagaimana sesuai dengan tujuan organisasi pemerintah.

Dalam melaksanakan agenda pembangunan, pemerintah Provinsi Kepulauan Riau berkomitmen mewujudkan birokrasi yang efisien, teknokratis, dan manajemen birokrasi yang diberdayakan untuk mengikuti perkembangan zaman. Dimulai dari proses rekrutmen yang transparan dan professional. Sejak tahun 2014, rekrutmen CPNS Provinsi Kepulauan Riau sudah menggunakan sistem Computer Assisted Test (CAT) yaitu 
168| Donie Tuah F. Kapabilitas Dynamic...

sebuah metode seleksi menggunakan komputer untuk mendapatkan standar minimal kompetensi dasar dengan penilaian kemampuan akademik dan bidang yang dibutuhkan.

Kemudian penempatan pegawai sesuai dengan kebutuhan organisasi yang didasarkan pada Analisis Beban Kerja (ABK) dan Analisis Jabatan (Anjab). Penempatan aparatur ini sangat penting, bukan hanya pejabat saja tetapi staf atau pelaksana juga penting karena akan berpengaruh besar pada kinerja organisasi pemerintahan. Orangorang yang ditempatkan ke dalam unit kerja tertentu diharapkan mampu memberikan kontribusi berupa gagasan, ide, kreatifvitas guna menunjang kinerja organisasi.

Kinerja organisasi dapat dilihat dari komposisi orang yang bekerja pada organisasi tersebut. Komposisi ini harus disesuaikan dengan kebutuhan beban kerja organisasi. Komposisi ini terkait dengan jumlah aparatur, kualifikasi pendidikan, dan kualifikasi jabatan. Dari data Badan Kepegawaian dan Pengembangan SDM Provinsi Kepulauan Riau tahun 2018, komposisi sumberdaya aparatur dari Organisasi Perangkat Daerah (OPD) teknis yang terkait dengan perekonomian daerah ${ }^{1}$ didominasi oleh PNS yang memiliki latar belakang pendidikaan DIV, S1, S2, dan S3 sebesar 79,83\%. Kemudian, pejabat di OPD teknis dominan diisi oleh PNS yang berlatarbelakang pendidikan DIV, S1, S2, dan S3 sebesar 94,32\%, dan hanya sebagian kecil pejabat yang berlatarbelakang pendidikan SMA dan DIII. Dari jumlah ini pemerintah Provinsi Kepulauan Riau memiliki kapasitas PNS yang mumpuni dalam penyelenggaran pemerintahannya, khususnya terkait dengan pembangunan ekonomi. Walaupun dari komposisi tersebut belum bisa menjawab secara pasti kapabilitas OPD teknis apakah dapat menjalankan tugas dan fungsinya dalam pencapaian target-target kinerja perekonomian yang ditetapkan, karena tentunya masih ada indikator lainnya selain hanya dari indikator pendidikan.

Peneliti juga melihat pada aspek pengisian jabatan-jabatan struktural di lingkungan pemerintah Provinsi Kepulauan Riau. Pengisian jabatan merupakan hak prerogative gubernur, dan merupakan kebijakan strategis. Sebelum berlakunya UndangUndang No. 5 Tahun 2014 tentang Aparatur Sipil Negara (ASN), gubernur dalam mengangkat seseorang dalam jabatan hanya melalui pertimbangan Badan Pertimbangan Jabatan dan Kepangkatan (BAPERJAKAT) dan walaupun sebenarnya hal ini merupakan

\footnotetext{
OPD yang dimaksud ialah:

a. Badan Perencanaan Penelitian dan Pengembangan;

b. Biro Administrasi Perekonomian;

c. Biro Administrasi Pembangunan;

d. Biro Administrasi Layanan Pengadaan;

e. Dinas Tenaga Kerja dan Transmigrasi;

f. Dinas Koperasi dan UKM;

g. Dinas Perindustrian dan Perdagangan;

h. Dinas Pariwisata;

i. Dinas Perhubungan;

. Dinas Kelautan dan Perikanan;

k. Dinas Penanaman Modal dan PTSP.
} 
kegiatan formalitas belaka. Kemudian, pasca diberlakukan Undang-Undang No. 5 Tahun 2014 tentang Aparatur Sipil Negara (ASN) maka pengisian jabatan esselon II (Jabatan Tinggi Pratama) harus melalui mekanisme seleksi terbuka (open bidding) secara terbuka dan kompetitif di kalangan PNS dengan memperhatikan syarat kualifikasi, kompetensi, kepangkatan, pendidikan dan pelatihan, rekam jejak jabatan, dan integritas serta persyaratan jabatan lain sesuai dengan ketentuan peraturan perundang-undangan. Tujuannya adalah untuk mendapatkan orang yang tepat di jabatan-jabatan yang ada di pemerintah Provinsi Kepulauan Riau guna meningkatkan kinerja dan efektivitas penyelenggaraan pemerintahan dan pembangunan.

Kebijakan pengisian JPT melalui seleksi terbuka telah merubah paradigma dalam manajemen kepegawaian. Selama ini pendekatan dalam pengisian jabatan di pemerintah menggunakan closed career system yang sangat berorientasi kepada senioritas dan kepangkatan. Dengan diberlakukannya UU ASN, pendekatan diubah ke arah open career system yang mengedepankan kompetisi dan kompetensi PNS. Perubahan pendekatan ini dimaksud untuk mendorong PNS untuk terus meningkatkan kapasitasnya. Selain itu, penerapan seleksi terbuka juga dimaksud untuk mengatasi intervensi politik dalam pengangkatan, pemindahan dan pemberhentian PNS.

Dalam kurun waktu periode penelitian ini, Pemerintah Provinsi Kepulauan Riau telah melaksanakan pengisian jabatan melalui seleksi terbuka sebanyak 2 (dua) kali, yakni pada tanggal 7 November 2016 dan 3 Januari 2017. Dari pelaksanaan kedua pengisian jabatan tersebut diindikasikan melanggar aturan, sebagaimana beberapa temuan dari Komisi Aparatur Sipil Negara (KASN) sebagai pengawas pelaksanaan pengisian jabatan. Berdasarkan surat KASN Nomor B-828/KASN/3/2017 tentang Hasil Pengawasan Pengisian Jabatan Pimpinan Tinggi Administrator dan Pengawasan di Pemerintah Provinsi Kepuluan Riau ditemukan 3 (tiga) permasalahan, yaitu: (1) pemberhentian 10 orang pejabat Pimpinan Tinggi Pratama yang tidak jelas alasan pemberhentiannya. (2) ada peserta seleksi terbuka Jabatan Pimpinan Tinggi Pratama yang tidak memenuhi persyaratan namun dinyatakan lulus seleksi. (3) ketidakprofesionalan panitia seleksi (pansel) dalam mengumumkan nilai peserta. Dengan adanya polemik terkait dengan pengisian jabatan ini tentunya sangat mengganggu penyelenggaraan pemerintahan.

Berkaca dari permasalahan di atas, seleksi terbuka seharusnya dilakukan dengan baik dan prosedural, mulai dari penentuan kriteria penilaian, tim penilai, keterbukaan dan dapat dipertanggungjawabkan, sehingga tidak menimbulkan pandangan negatif masyarakat terhadap hasil seleksi tersebut. Artinya proses dan hasil seleksi harus mencerminkan tata kelola pemerintahan yang baik dan akuntabel, sehingga hasil seleksi dapat diterima semua pihak, tidak menimbulkan rasa curiga. 
170| Donie Tuah F. Kapabilitas Dynamic...

\section{E. Agile Process}

Kebijakan adaptif bukanlah hanya sebagai reaksi pasif terhadap dinamika eksternal tetapi ini lebih sebagai sebuah pendekatan proaktif terhadap inovasi, kontekstualisasi dan eksekusi kebijakan. Pemerintah harus didorong untuk terus berinovasi. Ruang-ruang kebebasan dalam berinovasi bagi pemerintah harus terbuka. Perlu diingat bahwa inovasi kebijakan merupakan sebuah ide atau gagasan baru dan segar yang dimasukkan ke dalam suatu kebijakan sehingga dapat mencapai hasil yang berbeda dan lebih baik. Inovasi yang dikonversi menjadi sebuah kebijakan sehingga masyarakat akan menghargai dan mendukung kebijakan yang dibuat tersebut, yang akhirnya tingkat kepercayaan masyarakat terhadap kinerja pemerintahnya tinggi. Mereka yakin bahwa pemerintah dapat membantu untuk menyelesaikan berbagai problematika yang terjadi. Akan tetapi, inovasi ini bukan hanya tentang ide dan dan desain kontekstual saja tetapi harus dieksekusi sehingga menjadi nyata.

Proses formulasi hingga eksekusi atau implementasi kebijakan adaptif harus tepat, tangkas dan cepat. Karena jika tidak, maka permasalahan yang ada akan semakin besar sehingga kebijakan yang telah direncanakan belum tentu dapat menjadi solusi terhadap permasalahan tersebut. Begitu juga dengan fenomena penurunan pertumbuhan ekonomi Provinsi Kepulauan Riau. Dari data BPS Provinsi Kepulauan Riau tahun 2018 sebenarnya tren penurunan ini sudah terlihat dari tahun 2012. Namun pemerintah belum terlalu meresponnya karena angka pertumbuhan ekonomi Provinsi Kepulauan Riau masih dianggap wajar. Padahal jika fenomena ini dapat diatasi sejak awal, tentu penurunan pertumbuhan ekonomi hingga 2\% di tahun 2017 tidak akan terjadi (BPS Provinsi Kepulauan Riau, 2018). Karena sebenarnya pertumbuhan ekonomi itu berkelanjutan dari tahun ke tahun, kondisi perekonomian tahun ini akan berdampak pada perekonomian di tahun yang akan datang. Apalagi jika pemerintah tidak melakukan apapun untuk menstabilkan perekonomian. Maka yang terjadi adalah stagnasi ekonomi. Ketika hal ini terjadi bukan tidak mungkin peran pemerintah dalam perekonomian akan terabaikan. Sehingga tata kelola ekonomi (economic governance) berjalan tanpa pemerintah.

Penurunan pertumbuhaan ekonomi yang terjadi di tahun 2017 membuktikan bahwa ketika pemerintah Provinsi Kepulauan Riau terlambat merespon gejala-gejala perlambatan perekonomian maka penurunan pertumbuhan ekonomi yang terjadi semakin parah. Terlambatnya respon pemerintah juga dikarenakan permasalahan yang terjadi diinternal pemerintah itu sendiri, seperti proses pengisian jabatan wakil gubernur, sekretaris daerah, hingga pejabat-pejabat struktural yang berpolemik dan proses legislasi pengesahan APBD yang terlambat. Sehingga pemerintah tidak mampu memikirkan kebijakan-kebijakan strategis makro ekonomi unuk mengatasi fenomena penurunan pertumbuhan ekonomi ini. 


\section{F. Culture}

Budaya masyarakat Kepulauan Riau identik dengan budaya melayu yang terbuka. Keterbukaan ini berdampak berkembangnya kemajemukan masyarakat di Provinsi Kepulauan Riau. Keterbukaan dan menerima perubahan ini juga berdampak pada kehidupan sosial, ekonomi, dan politik. Masyarakat melayu tidak anti atau sentimen terhadap orang yang berasal dari luar daerahnya. Siapapun dapat hidup di bumi melayu, bahkan untuk menjadi pemimpin sekalipun. Yang terpenting ialah orang tersebut mampu memberikan kontribusi bagi daerah. Jika hal ini tidak dilakukan, maka masyarakat melayu tidak akan tinggal diam. Masyarakat melayu itu juga kritis terhadap sesuatu yang dianggapnya bertentangan dengan budaya apalagi dengan agama Islam. Ada ungkapan yang menunjukkan sikap kritis masyarakat melayu, yaitu "raja alim raja disembah, raja zalim raja disanggah". Sikap kritis ini bukan untuk menunjukkan sikap merasa paling benar sendiri, karena masyarakat melayu juga tidak anti kritik jika melakukan kesalahan dan mau untuk memperbaikinya. Budaya melayu mengajarkan masyarakatnya untuk terbuka terhadap perubahan dan akuntabel atau tanggungjawab dengan apa yang dikerjakan. Budaya inilah yang diperlukan untuk mendorong proses perubahan dan menjadi ciri organisasi yang dinamis.

Di dalam visi misi Provinsi Kepulauan Riau tahun 2010-2015 dan tahun 20162021 ada sebuah frasa "berakhlak mulia" sebagai salah satu visi yang ingin diwujudkan. Berakhlak mulia mengandung arti bahwa masyarakat Provinsi Kepulauan Riau mampu mempertahankan nilai-nilai moralitas masyarakat melayu di mana agama Islam menjadi sumber utama referensinya dengan dasar keimanan dan ketaqwaan kepada Tuhan Yang Maha Kuasa, dan bagi masyarakat selain Islam juga dapat melaksanakan ajaran agamanya, sehingga tercipta kerukunan antar umat beragama.

Institusi pemerintah juga harus membangun nilai-nilai budaya untuk dapat bekerja bersama-sama dalam membangun tata kelola pemerintahan dinamis yang bertumpu pada perubahan berkelanjutan. Internalisasi dan aktualisasi budaya ini bertujuan untuk mendukung atau bahkan menghambat perubahan dalam formulasi dan eksekusi atau implementasi kebijakan. Sehingga pemerintah dapat membuat kebijakan dan opsi kebijakan lainnya agar dapat bertindak secara efektif.

Budaya organsasi pemerintah yang dibangun harus sejalan dengan semangat reformasi birokrasi untuk mewujudkan pemerintahan yang baik. Budaya organisasi terkait dengan kinerja organisasi. Ketika budaya telah teriintegrasikan ke dalam organisasi maka secara otomatis kinerja organisasi juga akan meningkat. Hasil yang ingin dicapai dari penanaman budaya ini adalah bagaimana seorang aparatur berfikir, bersikap dan bertindak sesuai dengan tujuan organisasi, tidak melenceng dari norma- 
172| Donie Tuah F. Kapabilitas Dynamic...

norma sosial, budaya dan agama. Secara sederhana penanaman budaya ini untuk menghasilkan aparatur pemerintah yang baik.

Budaya kinerja organisasi pemerintah Provinsi Kepulauan Riau tertuang pada Peraturan Gubernur No. 31 Tahun 2015 tentang Budaya Kerja Aparatur di lingkungan pemerintah Provinsi Kepulauan Riau. Budaya kerja yang dikembangkan ialah Santun, Inovatif, Gigih, Akuntabel, dan Profesional (SIGAP). Budaya santun meliputi: penerapan senyum, salam, sapa, sopan dan santun; penerapan nilai-nilai agama dan budaya; saling menghormati. Budaya inovatif meliputi: bersikap terbuka memberi dan menerima ide/ gagasan baru; melakukan suatu nilai tambah pada organisasi; membangun breaktrough/ terobosan dalam memberikan solusi; memanfaatkan teknologi informasi dan komunikasi; selalu melakukan perbaikan dan penyempurnaan. Budaya gigih meliputi: tidak mudah menyerah terhadap beban kerja yang diberikan; bersemangat/ tidak malas; bekerja cepat/ responsif. Budaya akuntabel meliputi: bertanggungjawab penuh atas pikiran, perbuatan, emosi dan cara kerja, keputusan dan sikap di tempat kerja; tidak melempar tanggungjawab kepada orang lain; loyalitas dan totalitas pada negara dan pekerjaan sesuai aturan; jump up by law (melakukan terobosan tanpa melanggar aturan). Budaya professional meliputi: menguasai pengetahuan dan keterampilan di bidangnya; tidak menyalahgunakan wewenang; memahami administrasi dan peraturan pendukung; bertindak objektif, bebas dari rasa sentimen, benci maupun rasa malas, enggan bertindak dan mengambil keputusan; selalu meningkatkan mutu kerja/ menjaga kualitas kerja; selalu mengutamakan kepentingan umum; kerja jujur dan ikhlas.

Namun faktanya penanaman nilai-nilai budaya kerja ini belum terlaksana menyeluruh kepada setiap aparatur pemerintah. Sosialisasi yang dilakukan oleh Biro Organisasi dan Korpri baru 1 (satu) kali di tahun 2016. Sehingga masih banyak aparatur pemerintah yang belum mengetahui budaya kerja ini. Tentu ini sangat disayangkan, karena ditengah usaha pemerintah untuk membentuk dan menanamkan budaya kerja aparatur pemerintah SIGAP ini, justru OPD yang diberikan kewenangan tidak memiliki komitmen untuk terus melanjutkan kebijakan ini.

Fakta lainnya ialah dari hasil penilaian kepatuhan standar pelayanan publik yang dilakukan oleh Ombudsman Republik Indonesia, provinsi Kepulauan Riau berada pada zona kuning atau berprediket sedang. Dari 6 (enam) OPD yang dinilai hanya Dinas Penanaman Modal \& Pelayanan Terpadu Satu Pintu (DPMPTSP) yang mendapatkan nilai paling rendah dan berada di zona merah karena pelayanan publik yang dilakukan pada dinas tersebut buruk. Padahal DPMPTSP merupakan ujung tombak pelayanan publik yang mampu mendorong terciptanya iklim investasi yang kondusif dan berdampak pada peningkatan pertumbuhan ekonomi. Salah satu indikator yang menjadi catatan ialah perilaku aparat dalam memberikan pelayanan yang kurang ramah dan cepat. 
Pembentukan atau institusionalisasi nilai-nilai budaya bagi aparatur pemerintah sangat penting dilakukan agar dapat menjadi sebuah citra diri atau karakter dari pemerintah tersebut. Pembentukkan nilai-nilai budaya ini harus terus konsisten dilakukan dan dievaluasi untuk dapat menghasilkan aparatur pemerintah yang berkarakter. Sehingga stigma-stigma negatif yang selama ini berkembang di masyarakat, perlahan akan terkikis seiring berubahnya budaya kinerja aparat pemerintahnya.

\section{Kesimpulan Dan Saran}

Berdasarkan uraian pembahasan di atas, maka dapat disimpulkan bahwa kapabilitas pemerintah Provinsi Kepulauan Riau dalam pencapaian pertumbuhan ekonomi tahun 2012-2017 belum mencerminkan kapabilitas dynamic governance. Di mana empat dari enam indikator dalam dynamic governance, yaitu: thinking across, able people, agile process dan culture belum terwujud pada penyelenggaraan pemerintahan. Kemampuan thinking across untuk mengadopsi kebijakan ekonomi dari daerah lain tidak dilakukan. Dukungan able people yang masih kurang optimal karena dalam pengisian jabatan-jabatan struktural, walaupun sudah melalui seleksi terbuka (open bidding) masih didapati indikasi melanggar aturan. Kemudian agile process tidak berjalan karena terlambatnya pemerintah Provinsi Kepulauan Riau merespon gejalagejala perlambatan perekonomian yang sudah terlihat dari tahun 2012. Hal ini dikarenakan oleh faktor internal seperti proses pengisian jabatan wakil gubernur, sekretaris daerah, hingga pejabat-pejabat struktural yang berpolemik dan proses legislasi pengesahan APBD yang terlambat. Sehingga pemerintah tidak mampu memikirkan kebijakan-kebijakan strategis makro ekonomi untuk mengatasi fenomena penurunan pertumbuhan ekonomi ini. Terakhir dari aspek culture, penanaman budaya kerja SIGAP (Santun, Inovatif, Gigih, Akuntabel, dan Profesional) yang belum maksimal karena minim sosialisasi. Selain itu dua indikator lainnya, yaitu thinking ahead dan thinking again,walaupun dari dua kemampuan tersebut dapat berjalan hingga menghasilkan kebijakan adaptif namun implementasi kebijakan adaptif yang dihasilkan juga tidak konsisten dilakukan, bahkan ada yang tidak berjalan yang akhirnya tidak mampu meningkatkan pertumbuhan ekonomi daerah tahun 2012-2017.

\section{Saran}

Berdasarkan simpulan yang telah dikemukakan di atas, maka terdapat beberapa saran yang dapat dilakukan agar kapabilitas pemerintah Provinsi Kepulauan Riau mampu meningkatkan pertumbuhan ekonomi, seperti:

1. Pemerintah Provinsi Kepulauan Riau harus lebih mematangkan perencanaan pembangunan ekonomi dengan berkomitmen untuk membangun Kepulauan Riau 
174| Donie Tuah F. Kapabilitas Dynamic...

dari pinggir atau daerah yang masih kecil kontribusinya terhadap pertumbuhan ekonomi, seperti Kabupaten Natuna, Kabupaten Kepulauan Anambas, dan Kabupaten Lingga. Juga meningkatkan kontribusi dari sektor-sektor lain selain industri pengolahan, konstruksi, pertambangan dan penggalian. Kemudian juga konsistensi akan keberlanjutan kebijakan-kebijakan yang telah terbukti hasilnya.

2. Pemerintah Provinsi Kepulauan Riau juga harus berpikir out of the box, melakukan inovasi-inovasi kebijakan ekonomi yang tidak biasa. Di mana kebanyakan pemerintah hanya memikirkan investasi besar untuk dapat menyerap tenaga kerja yang banyak. Padahal pemerintah seharusnya lebih berpikir untuk menciptakan wirausahawan-wirausahawan melalui UKM yang terbukti stabil kondisinya karena pangsa pasarnya adalah dalam negeri.

3. Pemerintah Provinsi Kepulauan Riau harus meningkatkan sinergitas dan sinkronisasi pembangunan dengan stakeholder terkait. Akan lebih baik jika persoalan pembangunan ekonomi dicarikan solusi dan dilakukan bersama-sama, saling menghilangkan ego sektoral.

4. Kapabilitas pemerintah Provinsi Kepulauan Riau perlu ditingkatkan dengan peningkatan kompetensi kepemimpinan visioner dan teknis, khususnya di bidang ekonomi dan kebijakan publik. Juga membuka peluang lahirnya inovasi-inovasi baru dari birokrat itu sendiri.

\section{DAFTAR PUSTAKA}

\section{Buku-Buku}

Antariksa, Basuki, 2016, Kebijakan Pembangunan Kepariwisataan: Pengembangan Kepariwisataan yang Berkelanjutan dan Perlindungan Kekayaan Intelektual. Malang: Intrans Publishing.

Boediono, 1985. Teori Pertumbuhan Ekonomi, Yogyakarta: BPFE.

Creswell, John, W. 1994, Research Design Qualitative \& Quantitative Approaches, New Delhi: Sage Publication.

Jhingan, M. L, 2014. Ekonomi Pembangunan dan Perencanaan. Terjemahan D. Guritno. Jakarta: PT. Raja Grafindo Persada.

Kuncoro, Mudrajad, 2014. Otonomi Daerah, Menuju Era Baru Pembangunan Daerah Edisi 3. Jakarta: Penerbit Erlangga.

Neo, Boon Siong \& Chen, Geraldine, 2007. Dyanmic Governance: Embedding Culture, Capabilities and Change in Singapore, Singapore: World Scientific Publishing

Sugiyono, 2014. Metode Penelitian Kuantitatif, Kualitatif, dan Kombinasi (Mixed Methods). Bandung: CV. Alfabeta. 
World Bank, 1994. Governance, The World Bank's Experience, Washington: The World Bank.

UNDP, 1997. Reconceptualising Governance. New York: UNDP.

\section{Dokumen:}

Asia Competitiveness Institute, 2017. ACI Competitiveness Ranking and Simulation Studies: 33 Provinces and Six Regions of Indonesia.

Barenlitbang Provinsi Kepulauan Riau, 2018. Kajian Tentang Potensi Peningkatan Pertumbuhan Ekonomi Provinsi Kepulauan Riau tahun 2018.

BPS, 2018. Berita Resmi Statistik Pertumbuhan Ekonomi Nasional Tahun 2017.

BPS Provinsi Kepulauan Riau, 2018. Berita Resmi Statistik Pertumbuhan

Ekonomi Provinsi Kepulauan Riau Tahun 2017.

Dinas Pariwisata Provinsi Kepulauan Riau, 2019. Laporan Kinerja Dinas Provinsi Kepulauan Riau Tahun 2018.

Nota Kesepahaman Bersama Antara Pemerintah Provinsi Kepulauan Riau Dengan Pemerintah Kabupaten/ Kota Se-Provinsi Kepulauan Riau Tentang Pelaksanaan Program/ Kegiatan Pengentasan Kemiskinan di Provinsi Kepulauan Riau.

Ombudsman Republik Indonesia, 2017. Laporan Hasil Penilaian Kepatuhan Standar Pelayanan dan Kompetensi Penyelenggara Pelayanan Sesuai Undang-Undang No. 25 Tahun 2009 Tentang Pelayanan Publik.

RPJMD Provinsi Kepulauan Riau Tahun 2010-2015.

RPJMD Provinsi Kepulauan Riau Tahun 2016-2021.

\section{Makalah:}

BPS Provinsi Kepulauan Riau, 2017. "Memaknai Perlambatan Pertumbuhan Ekonomi Provinsi Kepulauan Riau Semester 1/ 2017 dan Kaitannya dengan Daya Beli Masyarakat". (Disampaikan pada acara Diskusi Pembangunan Terkait Pertumbuhan Ekonomi di Provinsi Kepulauan Riau, Tanjungpinang 10 Oktober 2017).

Kantor Perwakilan Bank Indonesia Provinsi Kepulauan Riau, 2017. "Diskusi Pertumbuhan Ekonomi Provinsi Kepulauan Riau". (Disampaikan pada acara Diskusi Pembangunan Terkait Pertumbuhan Ekonomi di Provinsi Kepulauan Riau, Tanjungpinang 10 Oktober 2017).

Mc Culloch, Neil \& Malesky, Edmund, 2010. Apakah Tata Kelola Pemerintahan Daerah yang Lebih Baik Meningkatkan Kinerja Pertumbuhan Ekonomi Daerah di Indonesia? Rasyid, Rafki, 2017. "Perekonomian Kepulauan Riau Tahun 2017". (Disampaikan pada acara Diskusi Pembangunan Terkait Pertumbuhan Ekonomi di Provinsi Kepulauan Riau, Tanjungpinang 10 Oktober 2017). 
176| Donie Tuah F. Kapabilitas Dynamic...

\section{Jurnal:}

Bohte, J \& Meier, Kenneth J. "The Marble Cake: Introduction Federalism to The Government Growth Eqution". The Journal of Federalism, Summer 2000: Volume 30, No. 3.

Kuznets, Simon. "Modern Economic Growth: Findings ang Reflections". The American Economic Review, June 1973: Volume 63, No.3.

Tahir, Muchlis M \& Nahruddin Zulfan. "Kapabilitas Dynamic Governance Dalam Optimalisasi Pengelolaan Lahan Terbuka Hijau Di Kota Makassar". Cosmogov, April 2017: Vol 3, No.1.

\section{Rujukan Elektronik:}

https://kepri.bps.go.id/site/pilihdata.html diakses pada tanggal 4 April 2019

http://www.djpk.kemenkeu.go.id/ visual/\#/tabel2 diakses pada tanggal 6 April 2019

\section{Peraturan:}

Peraturan Daerah No. 2 Tahun 2012 tentang Rencana Induk Pembangunan Kepariwisataan Daerah Tahun 2012-2022.

Peraturan Daerah No. 2 Tahun 2013 tentang Pembentukan Badan Usaha Pelabuhan PT. Pelabuhan Kepri.

Peraturan Gubernur No. 31 Tahun 2015 tentang Budaya Kerja Aparatur di lingkungan pemerintah Provinsi Kepulauan Riau

Peraturan Gubernur No. 50 tahun 2017 tentang Pelaksanaan dan Pengembangan Egovernment Provinsi Kepulauan Riau 